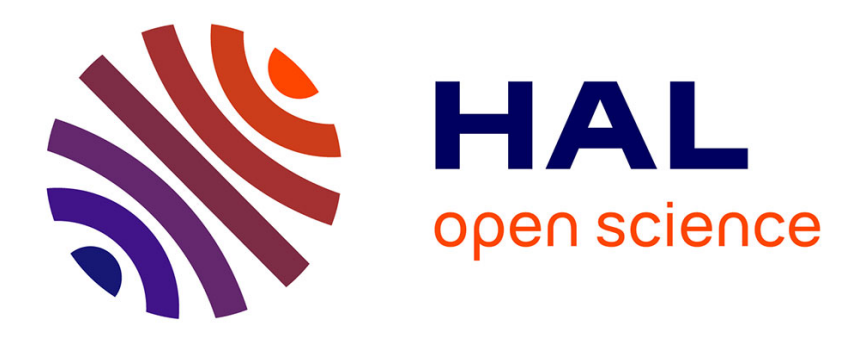

\title{
Income and Wealth Inequality in Hong Kong, 1981-2020: The Rise of Pluto-Communism?
}

Thomas Piketty, Li Yang

\section{To cite this version:}

Thomas Piketty, Li Yang. Income and Wealth Inequality in Hong Kong, 1981-2020: The Rise of Pluto-Communism?. 2021. halshs-03321889

\section{HAL Id: halshs-03321889 \\ https://shs.hal.science/halshs-03321889}

Preprint submitted on 18 Aug 2021

HAL is a multi-disciplinary open access archive for the deposit and dissemination of scientific research documents, whether they are published or not. The documents may come from teaching and research institutions in France or abroad, or from public or private research centers.
L'archive ouverte pluridisciplinaire HAL, est destinée au dépôt et à la diffusion de documents scientifiques de niveau recherche, publiés ou non, émanant des établissements d'enseignement et de recherche français ou étrangers, des laboratoires publics ou privés. 


\title{
Income and Wealth Inequality in Hong Kong, 1981-2020: The Rise of Pluto-Communism?
}

\author{
Thomas Piketty
}

Li Yang

June 2021

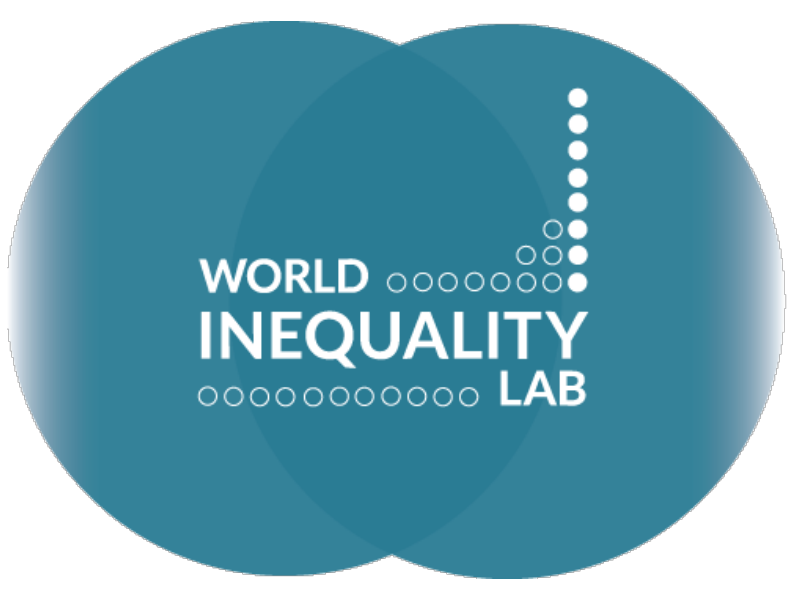

WID.WORLD

THE SOURCE FOR GLOBAL INEQUALITY DATA 


\title{
Income and Wealth Inequality in Hong Kong, 1981-2020: The Rise of Pluto-Communism?
}

\author{
Thomas Piketty and Li Yang ${ }^{1}$ \\ June 2021
}

\begin{abstract}
This paper combines national accounts, household surveys, fiscal data, wealth rankings and election polls, in order to provide a comprehensive analysis of the evolution of income and wealth inequality in Hong Kong, as well as its impact on political cleavages over the 1981-2020 period. We find a very large rise in wage inequality since 1981, especially since the Handover of Hong Kong to China. Top $1 \%$ earners now receive a much larger fraction of the total wage bill than bottom $50 \%$ earners, while the opposite was true in pre-Handover Hong Kong. We also observe an enormous increase in the capital share and the top wealth share (normalized by national income) since 2000. Today Hong Kong's very top wealth share (top $0.001 \%$ ) is ranked at very top in the world. Finally, we find that the top income earners and high-income professions (such as executives and managers) are more likely to vote for pro-Beijing camp, while the bottom $85 \%$ income group, students and lower-income professionals are more likely to be pro-democratic.
\end{abstract}

\footnotetext{
1 Thomas Piketty: Paris School of Economics, piketty@psemail.eu; Li Yang: Paris School of Economics and INSEAD, li.yang@psemail.eu. The author would like to Regina Huang for her contribution in data collection. This research is supplemented by a data appendix that is available on-line on WID.world.
} 


\section{Introduction}

The recent wave of Hong Kong protests (2019-2020) has drawn extensive global attention from all over the world. Since June 2019, the on-going protests have escalated from a demonstration against a proposed extradition law into a much wider and prolonged anti-government and anti-Beijing movement that has resulted in increasingly violent clashes and upset the economic and social order of the city. To a large extent, there has been an escalating social unrest in Hong Kong over the past twenty years (i.e., the $20031^{\text {st }}$ of July protest and the 2014 Umbrella Revaluation). It is generally believed that beneath the political issues about democratic rights which trigged the protests directly, there is also a bedrock of economic and social conditions that nurtured the development of social unrest, in which the city-state's rising inequality and extreme concentration of wealth is the most important one (Ng, 2013; Nagy, 2015; So, 2016; Dieter, 2019).

By combining a large number of data sources (household surveys, tax data, wealth rankings, national accounts, election polls) and innovative methodologies, we aim to provide in this paper a comprehensive analysis on the evolution of income and wealth inequality in Hong Kong for the last four decades, as well as its impact on political cleavages and voting patterns. We find a very large rise in wage inequality since 1981 , especially since 2000 . We also observe an enormous increase in the capital share and the top wealth share (normalized by national income) between 2000 and 2020. Today Hong Kong's very top wealth share (top $0.001 \%$ ) is ranked at very top in the world. Finally, we find that the top income earners and highincome professions (such as executives and managers) are more likely to vote for pro-Beijing camp, while the bottom $85 \%$ income group, students and lower-income professionals are more likely to be pro-democratic.

Our results raise interesting questions about the nature of the political regime that is currently in power in Hong Kong and Beijing. In particular, the case of Hong Kong 
illustrates an intriguing and probably unique example in history of a country becoming more unequal in terms of income and wealth after becoming officially "communist", or at least after joining a communist regime, following the 1997 Handover of Hong Kong to the People's Republic of China. In order to characterize this paradox, we coin the term "pluto-communism", i.e. a form of communism dominated by the power of money. It is also worth pointing out the lack of transparency about income and wealth inequality in Hong Kong (as well as in the PRC in general). In particular, the inheritance tax was abolished in 2006, so that we have no data at all on inheritances in Hong Kong (nor in the PRC). In this paper we attempt to do our best by combining the data sources at our disposal, but it is clear that one would need to access more detailed sources (especially on wealth and capital incomes) in order to reach a finer understanding of the forces at play.

This paper contributes to the existing literature in several ways. First, we apply new methods to combine the salary tax data and census data. To our knowledge, it is the first time that the salary tax data and census data are jointly used to estimate wage inequality in Hong Kong. Our estimates provide sharp upward revision of official wage inequality estimates for the period 1981 to 2018 . For instance, the top $1 \%$ wage share rose from $10.7 \%$ to $16.3 \%$ between 1981 and 2018 , while the bottom $50 \%$ share dropped from $18.7 \%$ to $11.6 \%$. Furthermore, to understand the drivers of rising wage inequality in Hong Kong, we adopt the Blinder-Oaxaca-type decomposition based on the Recentered Influence Function (RIF) of the Gini index (Firpo, Fortin, and Lemieux, 2009, 2018). Our results show that in pre-Handover Hong Kong (1981-1996), the changing pattern of education structure and wage premia and the transformation of industrial structure from manufacturing sector to non-manufacturing sector (finance and service) were the major driving force for the rise of wage inequality. In the post-Handover period (1997-2018), the latter factor becomes the only driver for the rise of wage inequality. In particular when further decomposing the effect of changing industrial structure into composition effects (mechanical changes in the workforce composition) and wage structure effects (change in skill prices), we find wage structure effects account for the lion's 
share. To this point, our findings complement the existing studies, which show that the rise of producer services and outward processing trade are the major cause of the rise of wage inequality (Chiu and Lui, 2004 and Ho et al., 2005). Education and labor policies were unable to counteract these forces. Furthermore, we find that rising female labor participation and the increasing share of Hong Kong born employees contribute negatively to the evolution of wage inequality.

Next, wealth or capital income data of Hong Kong are extremely limited in both aggregated and household level, largely due to the absence of a comprehensive progressive tax on capital income and wealth in Hong Kong. Consequently, the evolution of Hong Kong's capital share has not yet been documented in the literature. Our third contribution is to bridge this gap by constructing a new Hong Kong's capital share proxy based on corporate profit tax data, balance of payment and national accounts. The capital share of Hong Kong has tripled since the recovery of the 1998 Asian Financial Crisis, from about $15 \%$ of national income to $45 \%$ in 2020. In 1990s, Hong Kong's capital share was lower than the level in most of the high-income nations. Today, Hong Kong's capital share is more than 1.5 times of the capital share in high-income nations.

Fourthly, we also contribute to estimate the wealth inequality of Hong Kong. Similar to the capital share, due to the lack of data, there is no systemcally study on wealth inequality of Hong Kong in the literature. We contribute to the literature by constructing the first set of international comparable measurements of the top wealth concentration for Hong Kong based Forbes Rich Lists. Hong Kong's wealth concentration level appears to be one of the highest in the world. If we compare billionaire wealth or top $0,001 \%$ wealth to national income, then Hong Kong is far above all other countries in the world. If we express top $0,001 \%$ wealth as a fraction of total wealth (which appears to be relatively high as compared to national income in Hong Kong), then Hong Kong's top 0,001\% wealth share is close to $10 \%$ in 2020 , which is comparable to the wealth concentration level in Russia, and much higher than what it is in countries the USA or China. 
Finally, we contribute to the understanding of the determinants of political attitudes. Political cleavages in Hong Kong are strongly divided over the attitudes toward the Chinese government and the democratization process. This has been widely studied in the literature (see Li $(1995,2000)$, and Wong (2017)). However, due to lack of data, there are very few empirical studies systemically investigating the relationships between income inequality and political cleavage in Hong Kong. ${ }^{2}$ Using the unique data set from the pre-nomination survey for the 2016 Legislative Council Election, we apply logit regression to estimate the determinants for political attitudes. Our findings show that the top income earners and high-income professions, such as executives and managers are more likely to vote for "status quo" (which in effect amounts to pro-Beijing attitudes), while the bottom 85\% income group, students and lower-income professionals are more pro-democratic.

The rest of this paper is organized as follows. In section 2 we describe our main data sources and methods. In Section 3, we present our results on the evolution of wage inequality and discuss the drivers of inequality trend. Section 4 and 5 discuss the methods and results of the estimation of capital share and wealth inequality, which we also compare to other countries. In section 6 , we further investigate the relationships between income inequality and political cleavages in Hong Kong. Section 7 provides concluding comments. This paper is supplemented by an extensive online appendix that includes all our raw data sources and computer codes and presents additional robustness checks. ${ }^{3}$

\section{Data Sources and Methods}

This paper combines several categories of data sources: household surveys,

\footnotetext{
2 Among the limited existing studies, Wong (2000a, 2000b) studied the shift of the positions of Hong Kong parties in terms of redistributive ideology and the relationship between individual's sociological and psychological factors and the attitude towards to redistribution respectively. See also Durrer and Gethin (2021).

${ }^{3}$ Appendix A-E will be published together with the paper. Full data appendix is available upon request.
} 
censuses and fiscal data; national accounts and wealth rankings; election polls. We describe each of them in turn.

First, for estimating the evolution of wage inequality as well as its drivers, we use 8 waves of random Micro Sub-samples of the Hong Kong Census provided by the Census and Statistic Department of Hong Kong covering the period 1981 to 2016. For waves 1981 and 1986, the sub-sample data set covers $1 \%$ of the full Census. For the rest of the waves, the sample data set covers $5 \%$ of the full Census (i.e., the sample covers 366,319 individuals in Census year 2016). Additionally, to improve the estimation of wage inequality, we combine the Census data with tabulated fiscal income data from Hong Kong salaries tax assessment, published in the Hong Kong Inland Revenue Department Annual Reports. ${ }^{4}$

Next, we construct a new Hong Kong's capital share proxy based on corporate profit tax data, balance of payment and national accounts. In particular, data on corporate profits tax is taken from annual reports from the Hong Kong Inland Revenue Department for the period 1989 to $2018 .^{5}$

Thirdly, we estimate the evolution of wealth concertation for the super-rich in Hong Kong. To do so, we rely on so-called "Rich Lists" regularly published in the Forbes magazine. We use the rich list for the years 1988 until 2019. Before 2007 the Forbes Magazine does not publish a separate rich list for Hong Kong. Therefore, for the years prior to 2008 data is taken from the world billionaires list. From 2008 to 2012, the data is from the so-called "Hong Kong's 40 Richest" list, the late data after 2012 is from the "Hong Kong's 50 Richest". Additionally, we also estimate the

\footnotetext{
${ }^{4}$ Hong Kong salaries tax covers the pretax total salary income, but not capital income or business income. For detailed tax rules of salaries please see Related Tax Rules of Guide to Tax Return, https://www.ird.gov.hk/eng/pdf/bir60 \_stl_e.pdf.

5 Hong Kong corporate profits tax covers profits from both domestic and foreign corporations as well as domestic and foreign unincorporated businesses in Hong Kong. Unincorporated business does not possess a separate legal identity from its owner(s). The owner(s) bear full liability for any action or inaction of the business: they may sue and be sued for business activity or inactivity. Unincorporated enterprises include sole proprietor-ships, partnerships and family trusts.
} 
aggregated value of private housing in Hong Kong based on the housing statistics published by Hong Kong Rating and Valuation Department. ${ }^{6}$

Finally, to investigate the determinants of political inclination, we use election survey data from the Public Opinion Program (POP) of The University of Hong Kong (HKU). ${ }^{7}$ In particular, our main analysis is based on the pre-nomination Survey for 2016 Legislative Council Election, which was conducted between June 20 and July 8, 2016 over 5,084 adult registered voters in Hong Kong who speak Cantonese. The pre-nomination survey contains information of interviewee of gender, age, education level, occupation, income level, and residential district, and political inclination, which allows us to estimate the determinants of political inclination based on logit model. As robustness check we also apply the same analysis to another election survey, namely 2016 Election Rolling Survey for Legislative Council Election, which provide less detailed information on education levels and occupation. ${ }^{8}$

\section{Rising Wage Inequality in Hong Kong}

In this section we first present our methodological approach and results for measuring wage inequality in Hong Kong, then analysis the drivers of the evolution of wage inequality.

\subsection{Measuring Wage Inequality}

We first measure wage inequality using pre-tax monthly wage income reported in

6 https://www.rvd.gov.hk/

7 Since 1991, POP provide various micro surveys of public opinions on elections, government, as well as important economic, social and political topics.

8 The 2016 Election Rolling Survey is a daily rolling survey, also conducted by Public Opinion Program (POP) of The University of Hong Kong (HKU) from July 30 to September 2 2016. For each day it interviews daily interviewing at least 200 adult registered voters in Hong Kong who speak Cantonese. For more details of both surveys, pleases see https://develo.pori.hk. 
Hong Kong census. This data source entails two main limitations. First, wage income in Hong Kong census is top-coded and the share of top-coded observations of the sample increases over time. I.e. in 1991 only $0.07 \%$ of the sample only report a top-coded wage income, while in 2016 the top-coded share increased to $0.35 \% .{ }^{9}$ Thus the sample will generate a downwards bias to the top of wage distribution. Furthermore, surveys often fail at capturing the top incomes because individuals from high-income strata typically have very low response rates in surveys (Piketty, Saez, and Zucman, 2018; Garbinti, Goupille-Lebret, and Piketty, 2018, Piketty, Yang, Zucman, 2019).

To account for these issues, we follow several steps in order to correct the rawcensus-data-based estimation. First, to tackle the top-coding issue, we assume that the top of the wage distribution of Hong Kong follows a Pareto distribution. This allows us to estimate the Pareto coefficient $\alpha$ using the data close to the cut off $C$. We then estimate the wage mean for the top-coded observations with the estimation of Pareto coefficient $\hat{\alpha}$ and $C$, which is subsequently assigned to all observations in the top-coded group.

Secondly, in order to address the fact that surveys often underestimate the top of the distribution, we use individual fiscal data from Hong Kong Salaries Tax Assessment to correct the top of the census data. More precisely, we adopt the reweighting method proposed in Blanchet, Flores, Morgan (2018) to combine tax tabulation and survey data (top decoded). The basic idea is to adjust the weight of the survey using fiscal data in a non-parametric manner under the assumption that fiscal data sets a credible lower bound on the number of people with given levels of income. Rather than directly making assumptions regarding the behavior of complex statistics such as quantiles or bracket averages (i.e., Piketty, Yang, and Zucman, 2019; Chancel and Piketty, 2017; Czajka, 2017; Morgan, 2017), their method makes easily interpretable assumptions at the observation level. By

${ }^{9}$ For more details on top-coding, please see Online Appendix D, sheet AX5. 
conducting simulations of the method and applications to real data (from France, Norway, the United Kingdom, Brazil, Chile), Blanchet, Flores, Morgan (2018) demonstrate the method improves the accuracy and precision of distributional estimates, even under extreme assumptions, and in comparison, to other survey correction methods using external data. For application of the method, also see Khalid and Yang (2021). 10

Figure 1 (panel A and B) presents the evolution of wage income shares (based on corrected survey) in Hong Kong from 1981 to 2018. We find consistent rising trends for both Top 1\% and Top 10\% wage shares. In stark contrast, the Bottom $50 \%$ share declined by $40 \%$ over this period. With respect to the Middle $40 \%$, its income shares first increased then decreased since 1996, diverging from to Top $10 \%$ shares. Wage inequality in Hong Kong has raised significantly since 1981, and particularly so since 1997-2000.

Figure 2 presents the evolution of wage Gini coefficients estimated basing on both corrected survey (solid line) and raw survey (dash line). The results are resembling yet striking. The corrected wage Gini raised about 12 percentage points from $50 \%$ since 1981; when measuring with raw survey, the pattern is largely similar except the level is much lower. After correction using the tax data, the inequality estimation is lifted substantially, i.e., about 6\% Gini percentage points in 2016.

Figure 1

Figure 2

We further look in to the growth rate of wage income in different income groups. Figure 3 shows two contrasting growth patterns for the period before and after the

10 To estimate corrected wage inequality in 2018, we first interpolate the 2018 raw wage distribution using 2016 Census and national account. We then apply the same correction using 2018 Salaries Tax Assessment. 
handover of Hong Kong in 1997. The wage growth rates of Hong Kong are strong and inclusive before the Handover. The average annual growth rate of wage income for the whole population is $7 \%$, while the growth rates of top $1 \%$ and bottom $50 \%$ are not too divergent, $8.2 \%$ vs. $6.1 \%$. After the Handover, Hong Kong features moderate but much less inclusive growth. The average growth rate is $3.1 \%$, less than half of the growth rate before the handover. Top 1\% grows more than 2.5 times of the bottom $50 \%, 4.6 \%$ vs. $1.8 \%$.

Figure 3

In our benchmark series, we measure wage inequality using the equal-split income concept, i.e. assuming that wage income is equally distributed among adults in a household. To this end, we convert the individual adult wage into the wage equalsplit among the adults in one household. We also provide in the appendix the series based upon individual wages, as well as series on the inequality of total income (labour and capital income) based upon the same correction coefficients as for wage income. ${ }^{11}$ We should stress however that the lack of proper fiscal data on capital incomes and wealth makes our series on total income inequality relatively uncertain (and probably underestimated). ${ }^{12}$ This is why we focus in this paper on wage inequality series and on the rise of the capital share and top wealth shares. The full results and the corresponding computer codes for wage and income inequality are available in the online appendix, where we also offer a complete description of the process and detailed robustness checks of the method.

\subsection{Drivers of Wage Inequality Trends}

What are the major drivers for the rising wage inequality trends in Hong Kong? To answer this question, we further look into the role of these socio-economic

11 See Appendix D, sheets 2.1-2.6 and Appendix E, sheets AF1A, AF1B, and AF2

12 See Appendix C. 
characteristics on level and evolution of the Gini index. In line with Firpo, Fortin, and Lemieux (2009, 2018), we adopt the Blinder-Oaxaca-type decomposition based on the Recentered Influence Function (RIF) of the Gini index. ${ }^{13}$ To be more precise, first, we regress the recentered influence functions (RIF) of Gini index on the explanatory socio-economic variables. ${ }^{14}$ With this approach we are able to estimate unconditional partial effects (UPEs) of the socio-economic characteristics (gender, education, industries, occupations, etc.) on the Gini index separately for each year. We then decompose the change in the Gini index over time and assess how the socio-economic characteristics impact the change of the Gini index over time. ${ }^{15}$ The simplest version of the RIF decomposition approach assumes that the conditional expectation of the RIF of Gini index $G$ for income $y, R I F(y ; G)$, can be modelled as a linear function of the explanatory variables, given by matrix $X$, such that the $\beta$ coefficients can be estimated by OLS:

$$
E(R I F(y ; G) \mid X)=X^{\prime} \beta
$$

Then, by the law of iterative expectations:

$$
G=E(R I F(y ; G))=E_{X}[E(R I F(y ; G) \mid X]=E(X) \beta
$$

This allows the estimation of standard partial effects (Unconditional Partial Effects) of the socio-economic characteristics. The $\beta$ coefficients can be interpreted as the marginal impact of a small change in $E(X)$ on the Gini index. From (2), we can then write the difference between the Gini of the reference and target distribution, which are two different time periods in our context, (with superscripts

\footnotetext{
13 Influence function (IF) is a widely used tool in the robust estimation of statistical or econometric models. As its name suggests the influence function $F(Y ; v, F y)$ of a distributional statistic $v(F y)$ represents the influence of an individual observation on that distributional statistic. Adding back the statistic $v(F y)$ to the influence function yields re-centered influence function (RIF).

14 The RIF function of the Gini is automatically estimated with the Stata command.

15 A thorough discussion of this methodology, comparing its econometric properties with other regression-based decomposition methods available in the literature, can be found in Fortin, Lemieux, and Firpo (2011).
} 
0 and 1) as:

$$
G^{1}-G^{0}=\bar{X}^{1^{\prime}} \beta^{1}-\bar{X}^{0^{\prime}} \beta^{0}
$$

Let us consider the counterfactual situation in which we give individuals in the target distribution the average characteristics of the reference distribution, while keeping their own coefficients. By adding and subtracting the inequality level in this counterfactual, $G^{0} 1=\bar{X}^{0^{\prime}} \beta^{1}$, re-arranging terms, we can rewrite the interdistributional differential in income inequality as:

$$
G^{1}-G^{0}=\left(\bar{X}^{1^{\prime}}-\bar{X}^{0^{\prime}}\right) \beta^{1}+\bar{X}^{0^{\prime}}\left(\beta^{1}-\beta^{0}\right)
$$

With such standard Oaxaca-Blinder decomposition, we are able analysis whether the changes in inequality are explained by mechanical changes in the workforce composition (composition effect), or whether they reflect changes in skill prices (wage structure effect). It is important to stress that the decomposition ignores general equilibrium effects, as it is based on the assumption that changes in quantities do not affect changes in prices.

Our analysis is based on the top decoded sample from Hong Kong Census. We further restrict this sample to all employees with age between 20 and 65, who were born in Hong Kong, China mainland, Macao and Taiwan. In particular, we use information on socio-economic characteristics, such as gender, age, marriage status, place of birth, education, industrial sector, occupation, and residential district. Income is measured by individual monthly wage.

Table 1, Column 1 to 3 present summary statistics of the key explanatory variables. Several strong trends can be observed for the period of 1981 to 2016 : (a) increase of female participation; (b) increase of Hong Kong born worker; (c) 
expansion of high education; (d) decreasing of manufacturing and rising of finance and service sector; (e) raise of professionals and managers.

Thus, in a nutshell, compared to 1981, in 2016, the employees in Hong Kong are more gender balanced, skilled and educated. They are also concentrated in nonmanufacturing sectors. We then look at the estimates from the RIF regressions for the Gini coefficient in column 4 to 6 . In our analysis, we focus on a set of key explanatory variables, namely gender, born place, education, industry, and occupation. We also control for age, marriage status, and residential districts in the regression. All the variables are dummies. The coefficients in the RIF regressions indicate the magnitude and direction of the expected change in the Gini index after a small increase in the average value of the corresponding variable, ceteris paribus. Thus, if the coefficient is 0.5 , it means that a $1 \%$ increase in the average value of corresponding variable increases the Gini by $0.05 \%$.

As shown in column 4, in 1981, the major variables contributing to higher Gini are higher education, share of professionals, and managers. Furthermore, female labor participation and the share of people born in Honk Kong increase the Gini index. In contrast, the industrial shift from manufacturing sector to nonmanufacturing sectors such as restaurants and hotels as well as wholesale and retail decreases the Gini index. In 2016 this picture flipped (column 6), all the variables of industrial sectors become inequality enhancing. Contrastingly, there is no more positive significant impact of female labor force participation and share of people born in Hong Kong. Higher education is inequality enhancing for all the period, but its effect decreases. Finally, share of professionals also became inequality diminishing while high wage occupation in administration and management remains the most inequality enhancing variable.

Column 7 to 10 present results for the standard Blinder-Oaxaca RIF Gini decomposition exercise. From 1981 to 1996, the Gini coefficient raises 8.6 percentage points from $32.7 \%$ to $42.8 \%$, which can be further decomposed to 
aggregated composition effects (14.1\%) and aggregated wage structure effects ($5.5 \%$ ). Correspondingly from 1996 to 2016 , the Gini coefficient raises $1.5 \%$, among which $6.9 \%$ is due to composition effects, $-5.4 \%$ is due to the change in skill price. For both periods, the wage structure changed in the way that it reduces the wage inequality, so the returns to the socio-economic characteristics become more balanced across the distribution. The composition effect has a positive sign, indicating that the changing composition of the work force is inequality enhancing. However, the composition effect decreases over time, while the wage structure effect remains almost the same.

Table 1

Aggregate composition and wage structure effect can be further decomposed by explanatory variables (socio-economic characteristics). Such decomposition enables us to calculate the overall contribution of each explanatory variable (or cluster of explanatory variables) to the change of Gini by adding up the composition effect and structure effect. Figure 4 presents overall effect by main explanatory variables calculated based on Table 1.

Before the Handover of Hong Kong (blue bars), expansion of education, especially higher education, is the major driving force for the rise of Gini coefficient. The change of industrial structure from manufacturing sector to non-manufacturing sector ranks at the second major inequality enhancing force. Rising female participation, increase Hong Kong born employee, and the occupational change towards to the high sill job in the labor force all play significant role to drive wage Gini down. After the Handover (orange bars), the change of industrial structure becomes the only driver for the rise of Gini, with the biggest absolute magnitude among all the drivers. In particular the whole industry effect on the Gini is mostly due to wage structure effects, the evolution of returns in finance and service sector contributed the most to the increase in overall inequality (see T1, as well as Appendix $E$, sheets AF5A and AF5B). Meanwhile the impact of education 
expansion and rising female participation on wage Gini diminish to almost 0; Increase in Hong Kong born employee, and the occupational change, especially increasing professionals, play even stronger role in reducing wage inequality.

Figure 4

\section{Rising of capital's share in income in Hong Kong}

In the last section, we presented the rising trend of labor income inequality, now we turn to discussion of capital income evolution in Hong Kong and its implication on inequity. In the most recent years, the research of inequality has been integrated with a focus on capital's share in income. According to Piketty (2013) and Piketty and Zucman (2015), capital shares have increased in all rich countries from about $15 \%$ to $25 \%$ in the 1970 s to $25 \%$ to $35 \%$ in $2010 .{ }^{16}$ Given that capital ownership is highly concentrated at the top, the rise of capital income will tend to increase both income and wealth inequality in the longer run (Piketty 2014, Bengtsson and Waldenström 2018).

Since Hong Kong's capital share are not provided in its national accounts, the evolution of Hong Kong's capital share has not yet been documented in the literature. To bridge the gap, we construct a new Hong Kong's capital share proxy based on corporate profit tax data, balance of payment and national accounts. We first retrieve the total amount of corporate pre-tax profits from the revenue of corporate profit tax. ${ }^{17}$ Since such corporate profit accrue to both Hong Kong citizens and foreign investors, we have to adjust it using the net direct investment and portfolio investment in order to only capture profits obtained by Hong Kong citizens. ${ }^{18}$ Finally, the estimation of capital share is equal to the share of the

\footnotetext{
16 Also see Ellis and Smith 2007; Azmat, Manning, and Van Reenen 2012; Karabarbounis and Neiman 2014

17 Profits tax covers both corporations and unincorporated businesses. Profits is net of fixed capital consumption. We assume imputed rent is equal to depreciation of the housing.

18 Hong Kong citizen owned corporate profits = Corporate profit in Hong Kong - Direct investment
} 
corporate profits obtained by Hong Kong citizens in national income.

Figure 5 presents the evolution of capital shares of Hong Kong and selected high income countries. Sharply contrasting to the capital share evolution in higher income countries, Hong Kong's capital share has gained substantial growth since the beginning of 1990s. Especially ever since the recovery of the Asian financial crisis, the capital share in Hong Kong rises from 12\% to about $38 \%$ in less than two decades. Capital share in Hong Kong was much lower than other high-income countries in the beginning of 2000s, today's capital share in Hong Kong reaches to the level that are no longer comparable to other high-income countries. Due to lack of micro data on household wealth and capital income ${ }^{19}$, it is impossible to estimate precisely the impact of rising capital share on income and wealth inequality. However, increasing evidence in the literature (Piketty 2014, Bengtsson and Waldenström 2018) shows that the distribution of substantially skewed to the right. This is also the case in Hong Kong, so that sharply rising capital share implies that capital (compare to labor) is increasingly becoming the driving force of rising income and wealth inequality.

Figure 5

\section{Wealth Inequality in Hong Kong}

There has always been intensive discussions and debates about the extreme wealth inequality in Hong Kong among the general public and the policy makers, however due to the lack of micro level wealth survey or administrative data,

and portfolio investment income paid to the rest of the world + Direct investment and portfolio investment income received from the rest of the world

19 This is mainly due to the absence (or very limited) tax on capital income in Hong Kong. To date, both capital gains and dividend income, whether from Hong Kong or overseas, are exempt from tax in Hong Kong. Interest income is subject to Hong Kong profits tax only where it is sourced in Hong Kong. Furthermore, there has never been a household wealth survey in Hong Kong. 
empirical studies are extremely limited till today.

To address this gap, in this section we provide for the first time a set of internationally comparable wealth concentration estimates based on the Forbes Rich Lists. Additionally, based on wealth accumulation model, we conduct simulations for the evolution of wealth inequality in Hong Kong over the period from 1981 to 2016. Our findings show that Hong Kong's wealth concentration level is at the very top of the world. Moreover, based on our simulation, the wealth inequality has been increasing for both period before and after 1996. In particular price effect and saving effect plays different role in the evolution of wealth shares for rich people and poor people over two periods.

\subsection{Measuring the Top Wealth Concentration of Hong Kong}

In the recent emerging literature on the evolution of wealth inequality, Forbes Rich Lists has been increasingly using to estimate the wealth concentration at the very top, often as consistency check or correction for the wealth survey and for the fiscal data (see Saez and Zucman 2016; Alvaredo et al. 2018; Novokmet et al. 2018; Piketty et al. 2019; Garbinti et al. 2021). The reliability of these lists is contentious due to several drawbacks. First the data is compiled relying on various sources and the methodology cannot be transparently evaluated. Second, the Rich Lists presumably neglect a number of private assets and liabilities, which may lead to the underestimation of wealth concentration. Last but not the least, the unit of analysis is not always consistent across observations, often it reports wealth for entire family consisting of more than one individual (or household). Further adjustment is required when using Forbes Rich List to estimate individual level wealth concentration.

Despite of above-mentioned drawbacks, the Rich Lists are the only source we could possibly rely on to estimate top wealth concentration in Hong Kong, where there is no wealth survey and no fiscal data on either capital incomes or 
inheritances (which can be used in a number of other countries). We would like to stress that our estimation still suffer from serious limitations, due to the lack of accurate statistical information both on the production and on the bias of this list. Our estimations have to be seen as first steps towards to a better understanding of the level and the evolution of the wealth concentration in Hong Kong.

To simplify our discussion, we treat each observation in the Rich Lists as a family, regardless it consists one or more individuals. Figure 6 present the number (Panel A, normalized by the adult population) and the total wealth (Panel B, measured by national income) of billionaire families ${ }^{20}$ in 2017 for 63 major economies in the world, sorted by national income per adult.

Figure 6

As striking as it appears, Hong Kong ranks at the very top for both wealth concentration statistics and its level is nowhere near the wealth concentration level in any other economy, regardless of the level of national income per adult.

In 2017, there are about 11 billionaire families every million adults in Hong Kong, while the number for Switzerland and Singapore, ranking at the second and the third, is 5.3 and 4.5. US, as a representative of high-income country with extreme wealth inequality, has 2.3 billionaire families per million adults. When we looking at the economies with similar income (50,000 $\$$ to 60,000 \$ national income per adult), Netherlands ranks as the lowest, it has only 0.8 billionaire families per million adults. Hong Kong is really a class of its own.

Switching to the total wealth of billionaire families, the picture is resembling. The total net wealth of Hong Kong billionaire families accounts for $85 \%$ of its national income in 2017, while besides Georgia, where the total net wealth of billionaire

20 Billionaire is defined as a family whose net wealth is more than one billion US dollars 。 
families account for $33 \%$ of national income, the level for all other countries is below $30 \%$. Such results confirm public concern about inequality in Hong Kong. The appealing truth is that Hong Kong's wealth concentration level is extremely server to the degree that it is not comparable to any other economy in the world.

How did wealth concentration in Hong Kong reach such an outstanding level? How does the wealth concentration evolve compared to other economies? To address these questions, we need to construct comparable wealth shares series across economies and along the time, which requires to estimate individual level (instead of family level) wealth statistics. So far there is no consensus in the literature on how to individualize the family wealth reported in the Rich Lists. ${ }^{21}$ In the present paper we adopt the following procedures to individualize the Rich Lists family wealth. We assume the average size of billionaire families are similar across economies and time (namely, 5 adults per billionaire family). Based upon this assumption, Figure 7 presents the evolution of top $0.001 \%$ wealth (normalized by national income) of Hong Kong and other countries for the period from 1988 to 2020. Panel (A) presents the estimations based on Forbes Rich Lists. In Panel (B), estimation of Hong Kong's top wealth is based on Forbes Rich Lists, series of top wealth in China, France, Russia, and the US are retrieved from the World Inequality Database.

As illustrated in both panel $(A)$ and panel $(B)$ of Figure 7 , the top $0.001 \%$ wealth increased substantially in Hong Kong during the last three decades, despite of several drops during the economy recessions. In the end of 1980 s, the top $0.001 \%$ wealth accounted for $17 \%$ of national income. At the time, it was comparable with other economies. By 2020 , it raised to $55 \%$ of national income, more than tripled compared to its level in 1988. The upwards trend is even more pronounced after the recovery of the Asia Financial Crisis. In consequence, today the level of Hong

\footnotetext{
${ }^{21}$ For example, Novokmet et al (2018), and Piketty et al (2019) and Alvaredo et al (2018) treat each billionaire as a married couple or an individual; while Garbinti et al. (2021) found that in order to reconcile the Challenges Lists (Rich Lists in France) with the administrative tax data, they would have to assume listed family size as much as $10-15$ individuals.
} 
Kong's normalized $0.001 \%$ wealth is well beyond the reach of other economies. Even Russia who is notorious for its high wealth concentration due to its business oligarchs, is pales in comparison.

\section{Figure 7}

However, an increase of normalized top wealth (relative to national income) does not necessarily mean raise of top wealth share, since it can be decomposed into the product of top wealth share and net private wealth-income ratio $\beta_{t}^{\text {private }}$ :

$$
\frac{W_{t}^{\text {top } 0.001 \%}}{Y_{t}}=\frac{W_{t}^{\text {top } 0.001 \%}}{W_{t}} * \frac{W_{t}}{Y_{t}}=\frac{W_{t}^{\text {top } 0.001 \%}}{W_{t}} * \beta_{t}^{\text {private }}
$$

Here, $Y_{t}$ indicates net national income in year $\mathrm{t}, W_{t}$ indicate net private wealth in year t. Hence, by construction the level of top wealth share is jointly determinate by the normalized top wealth and $\beta_{t}^{\text {private }}$. To calculate the top wealth share, we would first need to estimate the value of $\beta_{t}^{\text {private }}$ for Hong Kong.

Unfortunately, aggregate balance sheets and private wealth data are not published by the statistical authorities of Hong Kong. Here we make our own estimation of private wealth in Hong Kong using available information following the procedures below. First, we estimate the net private housing wealth in Hong Kong $\left(\beta_{t}^{\text {housing }}\right)$. Private housing stock and housing price (market value) are published regularly by the Rating and Valuation Department of Hong Kong ${ }^{22}$. Thus, we are able to estimate the market value of private housing in Hong Kong. Outstanding mortgage loan of Hong Kong, is published Hong Kong Monetary Authority ${ }^{23}$. Net private housing wealth is equal to the market value of private housing minus outstanding

22 https://www.rvd.gov.hk/

23 https://www.hkma.gov.hk/gb_chi/data-publications-and-research/data-and-statistics/monthlystatistical-bulletin/ 
mortgage loan (For details, please see Appendix D, sheet AX10). We then estimate the share of net housing wealth in private wealth $\left(A_{t}^{\text {housing }}\right)$, with which we are able to subsequentially estimate the level of private wealth in Hong Kong. Thus:

$$
\beta_{t}^{\text {private }}=\frac{\beta_{t}^{\text {housing }}}{A_{t}^{\text {housing }}}
$$

Figure 8 panel A presents the evolution of net private housing wealth in Hong Kong and other major economics in the world. Hong Kong's $\beta_{t}^{\text {housing }}$ started in quite low level compared to other economies in 1980s. Driven by the soaring of the assets price, it then raised to $363 \%$ national income in 1997. During the Asia Financial Crisis, it fell badly to $122 \%$ of national income in 2002 ; ever since it has raised phenomenally, in $2018 \beta_{t}^{\text {housing }}$ reach to $450 \%$, which is unparalleled by any other economies since 1980. What is the share of net housing wealth in private wealth $\left(A_{t}^{\text {housing }}\right)$ in Hong Kong? Recently, Citibank released a survey-based study on multimillionaires in Hong Kong ${ }^{24}$, according to which the share of housing in wealth portfolio is particularly large in the city-state, and in addition that it has been rising in the last decade: in 2018 housing wealth accounts for $75 \%$ of total net wealth of multimillionaires, while in 2012 the share it was $68 \%$. Housing wealth share in the top wealth group is generally lower than it in total private wealth, since wealthy people are more likely to hold more financial assets. Thus, we could see the housing wealth share of multimillionaires as the lower bound of $A_{t}^{\text {housing }}$. Comparing to other economies (see Figure 8, Panel B), Hong Kong's $A_{t}^{\text {housing }}$ is unusually high.

\section{Figure 8}

24 "Hong Kong Affluent Study 2019/2020" by Citigroup Inc. September 23, 2020. Multimillionaires are defined as those with total net assets of $\mathrm{HK} \$ 10$ million or more and liquid assets of at least HK\$1 million. 
Table 2 presents our estimation of the private wealth national income ratio and top $0.001 \%$ wealth share for Hong Kong and other major economies in the world. ${ }^{25}$ In the 2010s, the upper bond of Hong Kong's private wealth income ratio ( $\beta_{t}^{\text {private }}$ ) is between $576 \%$ to $593 \%$ of national income, in the similar level of Korea, Japan and France. Under these assumptions the lower bound of top $0.001 \%$ wealth share is between $83 . \%$ and $10.3 \%$, which reaches to the same level of the upper bond of top $0.001 \%$ wealth share in Russia ${ }^{26}$, and more than twice the level in US, 10 times of the level in France. In brief: expressed as a fraction of national income, billionaire wealth and top $0,001 \%$ wealth reach levels in Hong Kong that are far higher than any other country in the world; expressed as a fraction of aggregate private wealth (which is also particularly high in Hong Kong, though the data sources we have to measure this are imperfect), top $0,001 \%$ wealth shares in Hong Kong are on par with Russia and substantially higher than in all other countries.

\section{Table 2}

\subsection{Saving, Assets Prices and the Evolution of Wealth Concentration}

Now we move to discuss the evolution of wealth accumulation and concentration in Hong Kong. To structure our analysis, we follow the accounting framework adapted from Piketty and Zucman (2014), Saez and Zucman (2016) and Kuhn et al. (2020). Consider a simplified law of motion for wealth of fractile i at time $t$ :

$$
W_{t+1}^{i}=\left(1+q_{t}^{i}+\sigma_{t}^{i}\right) W_{t}^{i}
$$

25 Data for other economies is retrieved from the World Inequality Database.

26 Estimation of top $0.001 \%$ wealth share of Russia is provided by Novokmet et al. (2018). When using Russia Forbes Rich Lists to estimate the wealth share at the very top, Novokmet et al. (2018) treat each billionaire family as one adult. Relaxing assumption on the family size of billionaires (i.e., to 5 adults) will significantly increase the population base and decrease the estimation of the wealth share. For example, under the same assumption, in 2015 the top $0.005 \%$ (not $0.001 \%$ ) wealth share in Russia is $9.8 \%$. Thus, the top $0.001 \%$ wealth share of Russia reported in Table 2 should be treated as the upper bound of the estimation. 
With $q_{t}^{i}$ capturing the contribution of capital gain to wealth growth, which is equal to the sum of the capital gain of different assets in the asset portfolio (e.g., housing, equity, savings); $\sigma_{t}^{i}=s_{t}^{i} Y_{t}^{i} / W_{t}^{i}$, capturing the contribution of savings to wealth growth. $s_{t}^{i}=S_{t}^{i} / Y_{t}^{i}$ is the saving rate or fractile i at time t.

Define net private wealth $W_{t}=\sum_{i=1}^{I} W_{t}^{i}$, national income $Y_{t}=\sum_{i=1}^{I} Y_{t}^{i}$, and the wealth share of fractile $\mathrm{i}$ in period $\mathrm{t}$ is $\omega_{t}^{i}=W_{t}^{i} / W_{t}$. Then the law of motion for the wealth share $\omega_{t}^{i}$ is

$$
\begin{gathered}
\frac{\omega_{t+1}^{i}}{\omega_{t}^{i}}=\frac{1+q_{t}^{i}+\sigma_{t}^{i}}{1+q_{t}+\sigma_{t}} \\
\Rightarrow \frac{\omega_{t+1}^{i}-\omega_{t}^{i}}{\omega_{t}^{i}}=\frac{q_{t}^{i}-q_{t}+\sigma_{t}^{i}-\sigma_{t}}{1+q_{t}+\sigma_{t}}
\end{gathered}
$$

Where $q_{t}=\frac{\sum_{i=1}^{I} q_{t}^{i} W_{t}^{i}}{W_{t}}, s_{t}=\frac{\sum_{i=1}^{I} s_{t}^{i} Y_{t}^{i}}{Y_{t}}, \sigma_{t}=\frac{s_{t} Y_{t}}{W_{t}}$

Let $\omega_{t+1}^{i}-\omega_{t}^{i}=\Delta \omega_{t}^{i}$

$$
\Rightarrow \frac{\Delta \omega_{t}^{i}}{\omega_{t}^{i}}=\frac{q_{t}^{i}-q_{t}+\sigma_{t}^{i}-\sigma_{t}}{1+q_{t}+\sigma_{t}}
$$

Let $r_{t}$ denote the average rate of return, $\alpha_{t}=\frac{r_{t} W_{t}}{Y_{t}}$ denotes capital share of national income at time t. By analogy, we define $\alpha_{t}^{i}=\frac{r_{t}^{i} W_{t}^{i}}{Y_{t}^{i}}$ as the capital share of fraction i at time $\mathrm{t}$.

$$
\Rightarrow \sigma_{t}=\frac{s_{t} Y_{t}}{W_{t}}=\frac{s_{t} r_{t}}{\alpha_{t}}, \text { and } \sigma_{t}^{i}=\frac{s_{t}^{i} Y_{t}^{i}}{W_{t}^{i}}=\frac{s_{t}^{i} r_{t}^{i}}{\alpha_{t}^{i}}
$$




$$
\Rightarrow \frac{\Delta \omega_{t}^{i}}{\omega_{t}^{i}}=\frac{q_{t}^{i}-q_{t}}{1+q_{t}+\sigma_{t}}+\frac{\frac{s_{t}^{i} r_{t}^{i}}{\alpha_{t}^{i}}-\frac{s_{t} r_{t}}{\alpha_{t}}}{1+q_{t}+\sigma_{t}}
$$

We denote as $\varphi_{t}^{q, i}=\frac{q_{t}^{i}}{q_{t}}$ the relative the asset price premium of fraction i at time $\mathrm{t}$, $\varphi_{t}^{r, i}=\frac{r_{t}^{i}}{r_{t}}$ the relative rate of return premium of fraction $\mathrm{i}$ at time $\mathrm{t}$.

$$
\Rightarrow \frac{\Delta \omega_{t}^{i}}{\omega_{t}^{i}}=\frac{q_{t}}{1+q_{t}+r_{t} * \frac{s_{t}}{\alpha_{t}}} *\left(\varphi_{t}^{q, i}-1\right)+\frac{r_{t}}{1+q_{t}+r_{t} * \frac{s_{t}}{\alpha_{t}}} *\left(\frac{s_{t}^{i}}{\alpha_{t}^{i}} * \varphi_{t}^{r, i}-\frac{s_{t}}{\alpha_{t}}\right)
$$

This equation decomposes the change in wealth share (in percentage) of fractile i to asset price effect $\frac{q_{t}}{1+q_{t}+r_{t} *_{t} \frac{s_{t}}{\alpha_{t}}} *\left(\varphi_{t}^{q, i}-1\right)$, and saving effect $\frac{r_{t}}{1+q_{t}+r_{t}{ }^{\frac{s}{s_{t}}} \frac{\alpha_{t}}{\alpha_{t}}} *\left(\frac{s_{t}^{i}}{\alpha_{t}^{i}} *\right.$ $\left.\varphi_{t}^{r, i}-\frac{s_{t}}{\alpha_{t}}\right)$. Based on the decomposition results, when holding aggregate parameters (i.e. $q_{t}, r_{t}, s_{t}, \alpha_{t}$ ) constant, the asset price effect in the change of wealth share is positively correlated with fractile i's relative asset price premium $\varphi_{t}^{q, i}$, while saving effect is positively correlated with i's saving rate $s_{t}^{i}$, relative rate of return premium $\varphi_{t}^{r, i}$, and the reciprocal of the capital share in its income. The above decomposition also allows to conduct simulations of the evolution of wealth shares. Due to lack of information on several key parameters for the period before 1996, our simulations focus only on the post-Handover period (1996-2016).

\section{Table 3}

The aggregate level parameters, namely $r_{t}, \alpha_{t}, s_{t}$, and $q_{t}$, are presented in Table 3. $r_{t}$ represents the real rate of return in Hong Kong for total private wealth, which is equal to weighted average real rate of return on different type of private assets. Since we do not have detailed data on rate of return by assets or shares 
of assets, here we use the prime rate ${ }^{27}$ in real terms ${ }^{28}$ as a proxy for $r_{t}$. For the whole period (1996-2016), the accumulated rate of return is $164 \%$ (yearly rate $5.0 \%) . \alpha_{t}$ represents the average capital share in national income over the period, calculated based on our estimation of capital share in previous section. $s_{t}$ represents average private saving rate, estimated based on Hong Kong's national accounts. $q_{t}$ is contribution of capital gain to wealth growth, which can be expressed as weighted capital gain of various assets (housing, equity, and savings), $q_{t}=\sum_{j}^{J} q_{t}^{j} A_{t}^{j}, A_{t}^{j}$ represents share of asset $\mathrm{j}$ in net private wealth at time t. We estimate real housing capital gain rate $q_{t}^{\text {housing }}$ based the price index for private domestic properties ${ }^{29}$ and CPI (see Figure 10 panel A). $q_{t}^{\text {equity }}$ is estimated based on Hong Kong stock market price index (HIS) deflated by CPI (see Figure 9 panel B). We assume the rate of capital gain on saving assets (deposit, loans, bonds) $q_{t}^{\text {savings }}$ equal to zero. National level capital gain in housing and equities are estimated based on housing and stock index, see Figure 9 (Panel A and B). We assume $q_{t}^{\text {savings }}$ equal to zero.

In order to estimate $q_{t}$, we also need to make assumption on the share of different assets in net private wealth $\left(A_{t}^{j}\right)$. Based on Figure 8 Panel $\mathrm{B}$, for most the rich countries, the housing share in net private wealth in 1996 is below $40 \%$. Due to the rising of housing price (see Figure 8 Panel A and Figure 9 Panel A), housing wealth national income ratio in Hong Kong is much higher than other countries, thus we assume the housing share $A_{1996}^{\text {houisng }}$ in Hong Kong is higher than other countries by assigning $A_{1996}^{\text {houisng }}$ equal to $50 \%$. We then split the rest of private wealth between equity wealth and non-equity financial wealth. Under such assumption, the contribution of capital gain to wealth growth $q_{t}$ is equal to $51 \%$ (see Table 3). We have to admit that to certain extent such assumption is arbitrary,

${ }^{27}$ prime rate is the interest rate that commercial banks charge their most creditworthy corporate customers.

28 deflated by consumer price index (CPI)

29 published by Census and Statistics Department of Hong Kong 
since we do not have further information on the portfolio of private wealth in Hong Kong, however after experimenting with different assumptions in the simulation, we find that our different assumptions result in the very similar evolution of wealth inequality.

We now simulate the evolution of wealth share for the wealth group in the bottom and at the top. Regarding Bottom wealth group, Figure 9 (Panel A and B) shows that in 1996, more than $50 \%$ the households own an apartment and less than $20 \%$ adult owns any stocks. Poon and Hon (2015) shows in 2014, the bottom 50\% income group in Hong Kong do not save or save very little ${ }^{30}$. Accordingly, we define bottom groups as: the households who do not own any property or equity $\left(\varphi_{t}^{q, i}=\right.$ 0 ) and do not save $\left(\frac{s_{t}^{i}}{\alpha_{t}^{i}} * \varphi_{t}^{r, i}=0\right)$. Simulation results shows the wealth share for bottom group will decrease $56 \%$ for the period of 1996-2016, while price effect and saving effect are equally responsible for the decrease of wealth share (price effect $=-26 \%$ vs. saving effect $=-31 \%$ ). Given in Hong Kong a significant share of household fall in this group, it is striking that their wealth share shrank so much.

We now move to top wealth groups. We define top wealth group as the superrich (top $0.001 \%$ ). We adopt moderate assumption by assuming the assets portfolio consist only equity $\left(A_{t}^{\text {equity }}=100 \%\right)$ and there is no capital gain premium within assets, thus the capital gain is equal to the market capital gain $\left(q_{t}^{i}=26 \%\right)$. We also adopt moderate assumption by assuming the saving rate of top group $\mathrm{A}\left(s_{t}^{i}\right)$ is $40 \% .{ }^{31}$ We assume relative rate of return premium $\left(\varphi_{t}^{r, i}\right)$ is equal to $150 \%$ and capital share $\left(\alpha_{t}^{i}\right)$ is equal to $80 \%$. Under such assumption, the total wealth share of top wealth group raises $9 \%$, which can be decomposed into $-14 \%$ of price effect and $23 \%$ of saving effect. Such results can be seen as the lower bound of the

\footnotetext{
${ }^{30}$ Households in the bottom 50 income group own less than $5 \%$ of total household savings, see Poon and Hon (2015).

31 Saez and Zucman (2016) shows that the saving rate of top 1\% wealth group in the US is between $30 \%$ to $45 \%$ for the period 1975 to 2012; Spaeth and Schmidt (2016) show that the saving rate of top 1\% wealth group in Germany is $25 \%$ in 2013 .
} 
estimation, due to our moderate assumption. Increase the capital gain or saving rate, or decrease the capital share in income will increase the wealth share of top wealth group. Our simulation also shows that the rise of equity price relative to the raise of housing price have a direct impact on the wealth share of the superrich through the channel of price effect, since the share of equity in the wealth portfolio of the superrich is often higher than the share of properties. By the same token, when housing price rising faster than equity price, than the wealth share for the middle class (house owners) will increase driven by the price effect. Such race between the stock market and the housing market and its impact on the evolution of wealth inequality have been carefully discussed in Kuhn et al. (2020) using US data. However, such race only matters for the people who have (property or equity). For those who do not own any real asset and only have small nominal savings, their wealth share will decrease while the assets price increase.

\section{Determinants of Political Attitudes in Hong Kong}

What are the relationships between inequality and political cleavages in Hong Kong? Are the top income earners and high-income professionals voting for the same pollical collations as others ? In this section, we are going to extend previous discussions and address these questions. Under Hong Kong's partial-democratic political structure, the Legislative Council (LegCo) has been formed by two sections, namely the Functional Constituencies (FC) and the Geographical Constituencies (GC). There are in total 70 seats in LegCo, which are equally distributed between two sections since 2004. GC members in LegCo are returned by direct elections from five geographical districts, while within functional constituencies, 5 seats attribute to district council, the other 30 seats are limited to about 230,000 voters in the other functional constituencies (mainly composed of business and professional sectors). The Chief Executive is elected by a 1200member Election Committee drawn mostly from the voters in the FC. By design, such system introduces certain disparity in representation between different constituencies. For example, big corporations, business elites, and political elites 
have privileged access to many constituencies with a small electorate, a handful of sectors have a much larger voter base.

Since the first direct elections of LegCo in Hong Kong in 1991, the major political cleavage dividing political parties has always been the attitude toward the Chinese government and the issue of democratization. The pro-democracy camp generally advocates a faster pace in democratization (including universal suffrage of the CE, abolition of the FC), the protection of the rule of law and a higher degree of autonomy. On the other hand, the pro-establishment (pro-Beijing) camp places less emphasis on the progress of democratization than the need for stability and harmony. They are more supportive of a closer integration between Hong Kong and the mainland. The Centrist represent those who do not take sides between the pro-democracy and pro-establishment camp. In practice they are closer to the proestablishment in the sense that they favor the status quo. The formation and evolution of political system as well as political cleavage in Hong Kong are very complex topics, which we are not able to fully unfold in this paper, for more detailed discussion, see Li (1995), So (2002), and Wong (2017). In this section we aim to understand the determinants for political inclination and contribute to the understanding of the relationships between income inequality and political cleavage in Hong Kong.

Our main analysis is based on the pre-nomination Survey for 2016 Legislative Council Election which was conducted over 5,084 adult registered voters (about $0.08 \%$ adult population). After dropping observations with missing values, the sample size reduces to 4310 . Table 4 column 1 to 4 present the summary statistics for the full sample and in each political camp. In the full sample, there are $14 \%$ interviewee support pro-establishment camp, versus 36.9\% supporting prodemocracy camp and $32.4 \%$ interviewee choose to stay central (neither proestablishment nor pro-democracy). Others mainly consist of people who do not have any clear political inclination. Since the income variables is not continuous variable (reported by income groups), to simplify our analysis, we build a top 
income dummy for top-income earners with monthly income higher than 40,000 HK\$ (about $5160 \$$ ). ${ }^{32}$ The shares of top-income earners do not differ significantly across different political camps (around 14.5\%). The centrists have slightly higher share than the rest. In terms of the occupation distribution, pro-establishment camp features highest share of Executives and Managers (14.6\%), production workers $(9.3 \%)$ as well as retirees $(38.9 \%)$, contrasting to pro-democracy camp with highest share in professionals $(20 \%)$ and students (12.9\%). Interestingly, the centrist contains the highest share in housewives and clerical and service workers. Average age of interviewee is 50 , pro-establishment voters are significantly older than the centrist and pro-democracy voters. Female ratio is highest among the centrist and lowest among the pro-establishment voters. Regarding the education level, pro-establishment camp contains highest share of voters with primary and secondary level education, while pro-democracy camp contains highest share of voters with higher education.

To better understanding the determinants for political inclination, we apply logit regression on political inclination dummies with the social and economic background of voters. We include voting district fixed effects (5 voting districts), standard error is clustered at the district level. The results are present in column 5 to 7 . As shown in the results, the top income group (compared to the bottom $85 \%$ ) is not significantly inclined with Pro-establishment Camp, but significantly less inclined to the Pro-democratic Camp. The possibility for the top income group to vote for the pro-democracy camp is $88 \%$ (odds ratio $=e^{-0.13}$ ) of the possibility for the bottom $85 \%$ to vote for the pro-democracy camp. Looking at occupations, the probability for the executives and managers to vote for pro-BJ camp is significantly

\footnotetext{
${ }^{32}$ In the survey data, the income variable is tabulated, the cut off is the highest threshold in income variable. One key difference between the electoral survey data that we use here and the electoral surveys used in other studies (such as the CSDS surveys used by Durrer and Gethin 2021) is that we have a bigger sample size and a more detailed income variable, so that we have enough observations to study the political attitudes of top income groups in a statistically significant manner. In addition the survey data used here allows to look at the "centrist" and not only at the "proestablishment" and "pro-democracy" factions. On the other hand the survey we use has many other limitations, including the fact that we can provide a longitudinal studies.
} 
higher than professionals ( odds ratio $=e^{-0.502}=61 \%$ ) or students ( odds ratio $=e^{-1.111}=33 \%$ ). Other occupations (i.e., clerical, service and production workers, housewives as well as retirees) are also less likely to vote for pro-establishment camp comparing to the executives and managers, but the effects are not statistically significant. For democracy camp, the results are just the opposite, except production workers, all other occupations have stronger inclination for pro-democracy camp, especially, the inclination for -pro-democracy of students and professionals is significantly higher than the executives and managers. Additionally, we found housewives are most likely to vote for the centrist, which is in line with the results in the summary statistics (column 2).

Last but not the least, inclination to pro-democratic camp also increases with education level and decreases by age, which is contrary to the pro-establishment camp, inclination decreases with education level and increases with age.

To conclude, our results show that the top income earners and high-income professions, such as executives and managers are more likely to vote for "status quo", the bottom $85 \%$ income group, students and professionals are more "prodemocracy". As robustness check we also apply the same analysis to 2016 Election Rolling Survey for Legislative Council Election, which provide less detailed information on education and occupation. The results from both surveys largely resemble each other (for results for 2016 Election Rolling Survey, see Appendix E, sheet AT2).

The alliance between the PRC government and Hong Kong business elites has been well studied in the literature (Goodstadt, 2000; Fong, 2014a, 2014b). Indeed, Beijing's attempt in the past to maintain prosperity may well have contributed to stretching the wealth gap, however there is still lack of systematical study to help us understand the impact of interwoven dynamics among governments of Mainland China and Hong Kong SAR, as well as Hong Kong business elites on rising inequality in Hong Kong. What seems certain is that the extreme level of 
inequality in Hong Kong play significant row at the development of social unrest in Hong Kong in the last decade. Probably with the same understanding, very recently the senior officials from Mainland China and Hong Kong SAR are discussing ways to broaden the city's tax structure and increase land supply in an effort to mitigate Hong Kong's inequality and high living costs (Zhai and Wong, 2021). ${ }^{33}$ Whether this will be sufficient to calm down public hanger with the rise of "pluto-communism" is very uncertain at this stage.

\section{Conclusion}

In this paper we have combined and confronted several data sources in order to analyze the evolution of income, wealth and electoral inequality in Hong Kong. We have used national accounts, surveys, wealth rankings, tax data, and election poll. We have obtained several main findings. First, wage inequality has raised in Hong Kong significantly in the last four decades, especially in the post-Handover period. Second, the capital share as well as the top wealth (normalized by national income) in Hong Kong have increased enormously since the beginning of the century. Today, Hong Kong is ranked at very top in the world in either the capital share, the top wealth, or the top wealth share. Finally, the top income earners and highincome professions, such as executives and managers are more likely to vote for pro-establishment camp, the bottom $85 \%$ income group, students and lowerincome professionals are more pro-democratic.

We should stress again that our study has many limitations, in particular due to the lack of adequate data access. The complete absence of fiscal data on capital income, wealth and inheritances is particularly problematic. We very much hope that more data will be available in the future in order to facilitate a finer understanding of inequality trends in Hong Kong and China.

\footnotetext{
${ }^{33}$ https://www.wsj.com/articles/china-targets-hong-kong-wealth-gap-housing-woes-after-political-
} purge-11615813651 


\section{Reference}

Alvaredo, Facundo, Anthony B. Atkinson, and Salvatore Morelli. 2018. "Top Wealth Shares in the UK over More than a Century." Journal of Public Economics 162: 26-47.

Alvaredo, Facundo, Bertrand Garbinti, and Thomas Piketty. 2017. "On the Share of Inheritance in Aggregate Wealth: Europe and the USA, 1900-2010." Economica 84: 239-60.

Azmat, Ghazala, Alan Manning, and John Van Reenen. 2012. "Privatization and the Decline of Labour's Share: International Evidence from Network Industries." Economica 79(315): 470-92.

Bengtsson, Erik, and Daniel Waldenström. 2018. "Capital Shares and Income Inequality: Evidence from the Long Run.” Journal of Economic History 78(3): 712-43.

Blanchet, Thomas, Ignacio Flores, and Marc Morgan. 2018. "The Weight of the Rich: Improving Surveys Using Tax Data World Inequality Lab." WID Working Paper Series No. 2018/12.

Chancel, Lucas, and Thomas Piketty. 2017. "Indian Income Inequality, 1922-2015: From British Raj to Billionaire Raj? World Inequality Lab.” WID Working Paper 2017/11

Chiu, Stephen W.K., and Tai Lok Lui. 2004. "Testing the Global City-Social Polarisation Thesis: Hong Kong since the 1990s." Urban Studies 41(10): 1863-88.

Citigroup Inc. 2020. Hong Kong Affluent Study 2019/2020. Hong Kong. https://www.citibank.com.hk/english/info/pdf/Citibank_Announces_Results_of_Hon g_Kong_Affluent_Study_2019-2020_Eng_final.pdf (June 16, 2021).

Czajka, Léo. 2017. "Income Inequality in Côte d'Ivoire: 1985-2014." WID Working Paper Series No. 2017/8.

Dieter, Heribert. 2019. "Inequality and Social Problems in Hong Kong: The Reasons for the Broad Support of the Unrest." Australian Journal of International Affairs.

Durrer, Carmen, Amory Gethin, "Inequality, Identity and the Structure of Political Cleavages in South Korea, Taiwan, and Hong Kong, 1996-2016", WID WP 2021/06

Ellis, Luci, and Kathryn Smith. 2007. "The Global Upward Trend in the Profit Share." BIS Working Papers.

Firpo, Sergio, Nicole Fortin, and Thomas Lemieux. 2018. "Decomposing Wage Distributions Using Recentered Influence Function Regressions." Econometrics 6(2): 28.

Firpo, Sergio, Nicole M. Fortin, and Thomas Lemieux. 2009. "Unconditional Quantile Regressions." Econometrica 77(3): 953-73.

Fong, Brian C.H. 2014a. Hong Kong's Governance Under Chinese Sovereignty . 2nd ed. 
Longdon: Taylor \& Francis Ltd.

2014b. "The Partnership between the Chinese Government and Hong Kong's Capitalist Class: Implications for HKSAR Governance, 1997-2012." China Quarterly 217(217): 195-220.

Fortin, Nicole, Thomas Lemieux, and Sergio Firpo. 2011. 4 Handbook of Labor Economics Decomposition Methods in Economics. Elsevier.

Garbinti, Bertrand, Jonathan Goupille-Lebret, and Thomas Piketty. 2018. "Income Inequality in France, 1900-2014: Evidence from Distributional National Accounts (DINA)." Journal of Public Economics 162: 63-77.

. 2021. "Accounting for Wealth-Inequality Dynamics: Methods, Estimates, and Simulations for France." Journal of the European Economic Association 19(1): 62063.

Goodstadt, Leo F. 2000. "China and the Selection of Hong Kong's Post-Colonial Political Elite." China Quarterly 163(163): 721-41.

Ho, Lok Sang, Xiangdong Wei, and Chung Wong Wai. 2005. "The Effect of Outward Processing Trade on Wage Inequality: The Hong Kong Case." Journal of International Economics 67(1): 241-56.

Karabarbounis, Loukas, and Brent Neiman. 2014. "The Global Decline of the Labor Share." Quarterly Journal of Economics 129(1): 61-103.

Khalid, Muhammed Abdul, and Li Yang. 2021. "Income Inequality and Ethnic Cleavages in Malaysia: Evidence from Distributional National Accounts (1984-2014)." Journal of Asian Economics 72: 101252.

Kuhn, Moritz, Moritz Schularick, and Ulrike I. Steins. 2020. "Income and Wealth Inequality in America, 1949-2016." Journal of Political Economy 128(9): 3469-3519.

Li, Pang-kwong. 2000. Hong Kong from Britain to China: Political Cleavages, Electoral Dynamics, and Institutional Changes. Aldershot, Brookfield, Singapore, and Sydney: Ashgate.

Li, Pang-Kwong. 1995. "Elections and Political Mobilisation: The Hong Kong 1991 Direct Elections." University of London.

Morgan, Marc. 2017. "Falling Inequality beneath Extreme and Persistent Concentration: New Evidence for Brazil Combining National Accounts, Surveys and Fiscal Data, 2001-2015."

$\mathrm{Ng}$, Angie. 2013. "Fighting Inequality in Hong Kong: Lessons Learned from Occupy Hong Kong | Ng | Radical Criminology." Radical Criminology 2: 47-68.

Novokmet, Filip, Thomas Piketty, and Gabriel Zucman. 2018. "From Soviets to Oligarchs: Inequality and Property in Russia 1905-2016." The Journal of Economic Inequality 16(2): 189-223. 
Piketty, T., and G. Zucman. 2014. "Capital Is Back: Wealth-Income Ratios in Rich Countries 1700-2010." The Quarterly Journal of Economics 129(3): 1255-1310.

Piketty, Thomas; 2014. "Capital in the 21st Century." Cambridge: Harvard Uni: 696.

Poon, Che Cheong, and Tai Yuen Hon. 2015. "Household Savings in Hong Kong: A Statistical Analysis." Journal of Family and Economic Issues 36(3): 353-68.

Saez, Emmanuel, and Gabriel Zucman. 2016. "Wealth in Equality in the United States since 1913: Evidence from Capitalized Income Tax Data." Quarterly Journal of Economics 131(2): 519-78.

So, Alvin Y. 2017. "A New Wave of Anti-Mainland Protests since 2012: Characteristics, Socio-Political Origins, and Political Implications." Asian Education and Development Studies 6(4): 333-42.

Späth, Jochen, and Kai Daniel Schmid. 2016. "The Distribution of Household Savongs in Germany." IAW Discussion Papers. https://ideas.repec.org/p/iaw/iawdip/128.html (June 16, 2021).

Stephen Robert Nagy. 2015. "Social Inequality and the Rise of Localism in Hong Kong." Asian International Studies Review 16(2): 25-47.

Thomas Piketty, Emmanuel Saez, and Gabriel Zucman. 2018. "Distributional National Accounts: Methods and Estimates for the United States." Quarterly Journal of Economics (revise \& resubmit).

Wong, Mathew Y. H. 2017. Comparative Hong Kong Politics Comparative Hong Kong Politics. Singapore: Springer.

Wong, Mathew Y.H. 2020a. "Party Competition and Ideology in Hong Kong: A New Manifesto Coding Dataset." Journal of East Asian Studies 20(2): 207-30.

. 2020b. "Welfare or Politics? A Survey Experiment of Political Discontent and Support for Redistribution in Hong Kong." Politics 40(1): 70-89.

Zhai, Keith, and Chun Han Wong. 2021. "China Targets Hong Kong Wealth Gap, Housing Woes After Political Purge ." The Wall Street Journal.

Zucman, Gabriel, Thomas Piketty, and Li Yang. 2019. "Capital Accumulation, Private Property and Rising Inequality in China, 1978-2015." American Economic Review forthcoming. 
Figure 1 (Panels A and B): Rising Wage Inequality in Hong Kong, 1981-2018
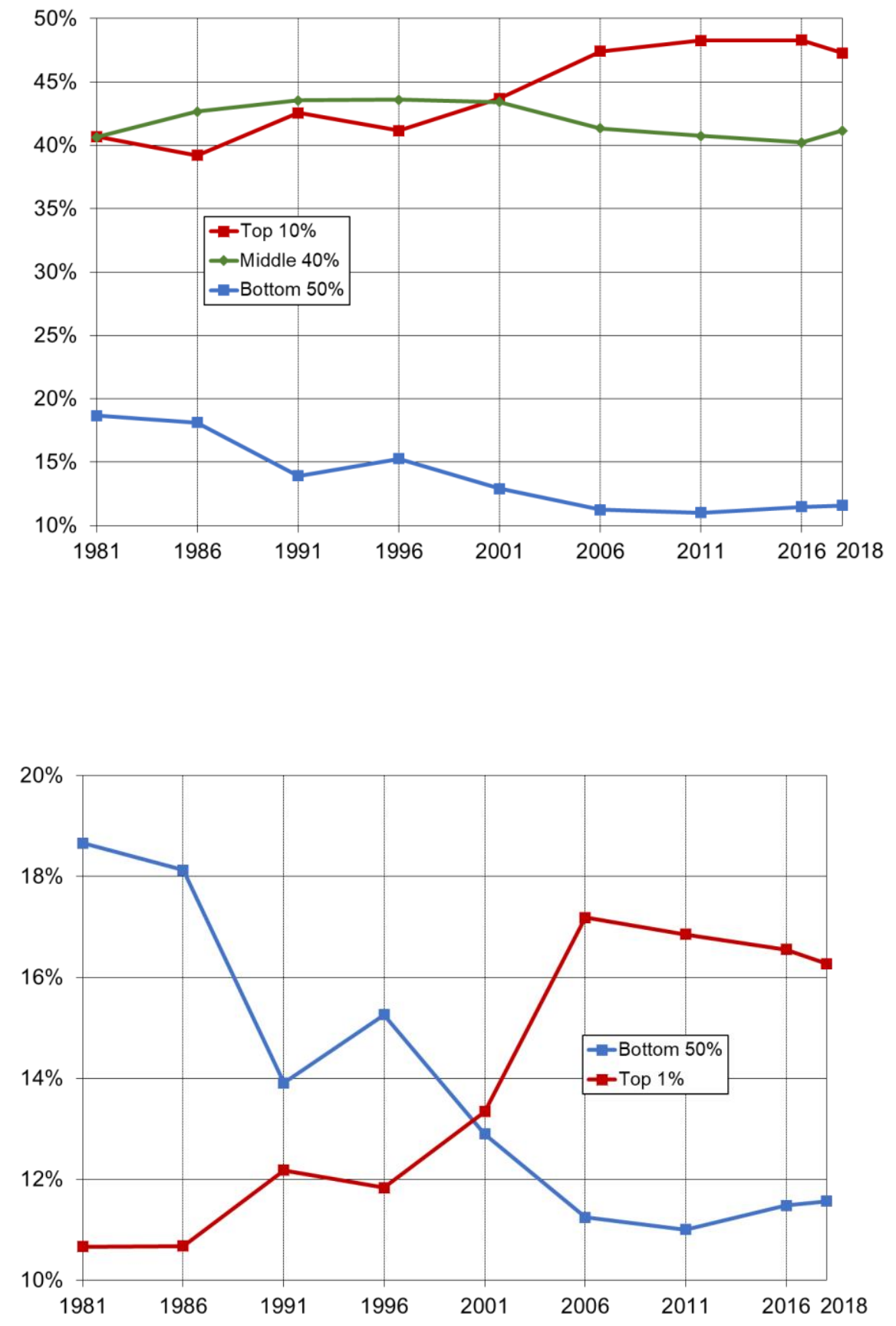
Figure 2: Evolution of Gini Coefficients for Wage Inequality in Hong Kong

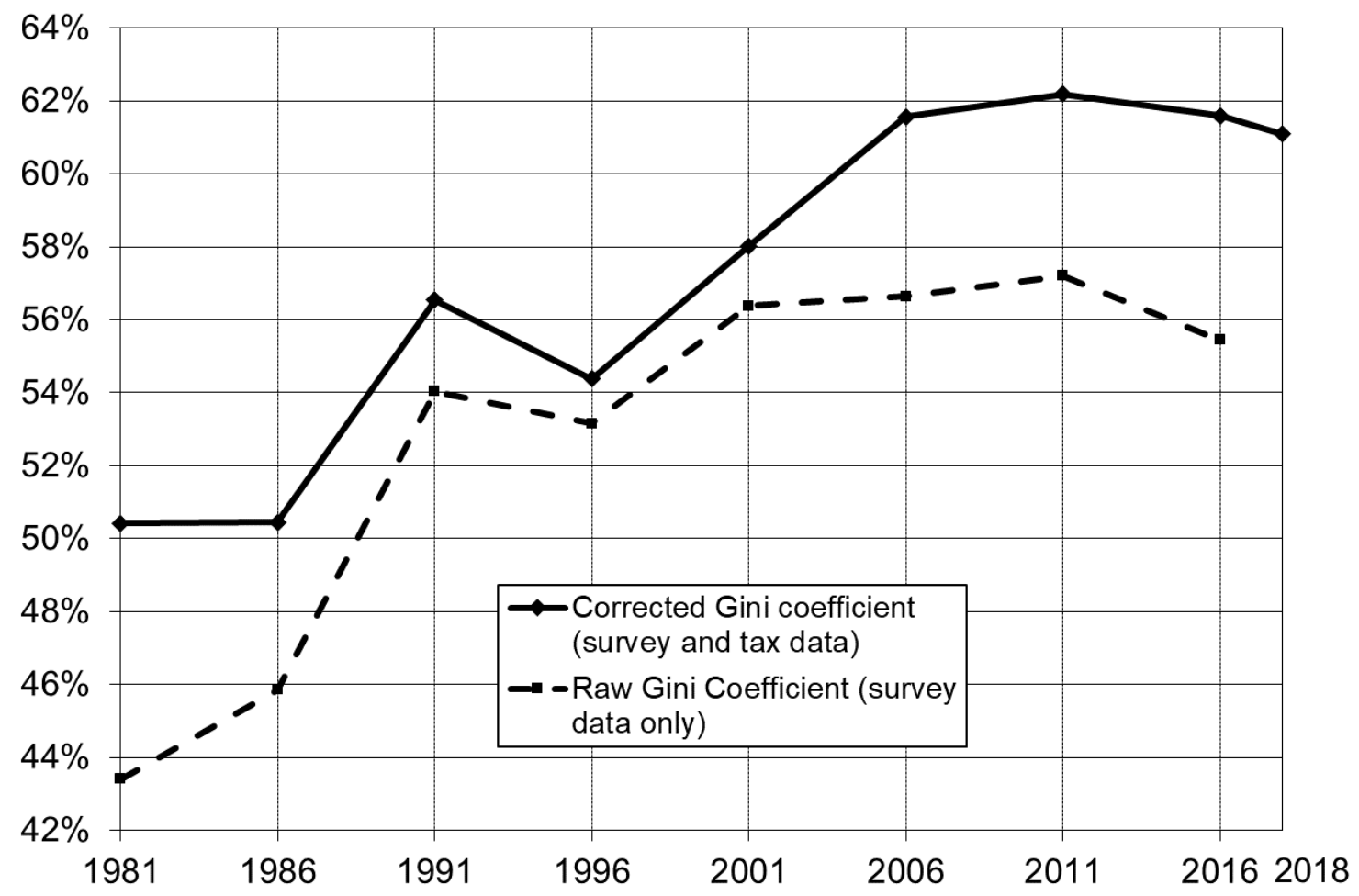


Figure 3: Real growth rate of wage income per adult in Hong Kong

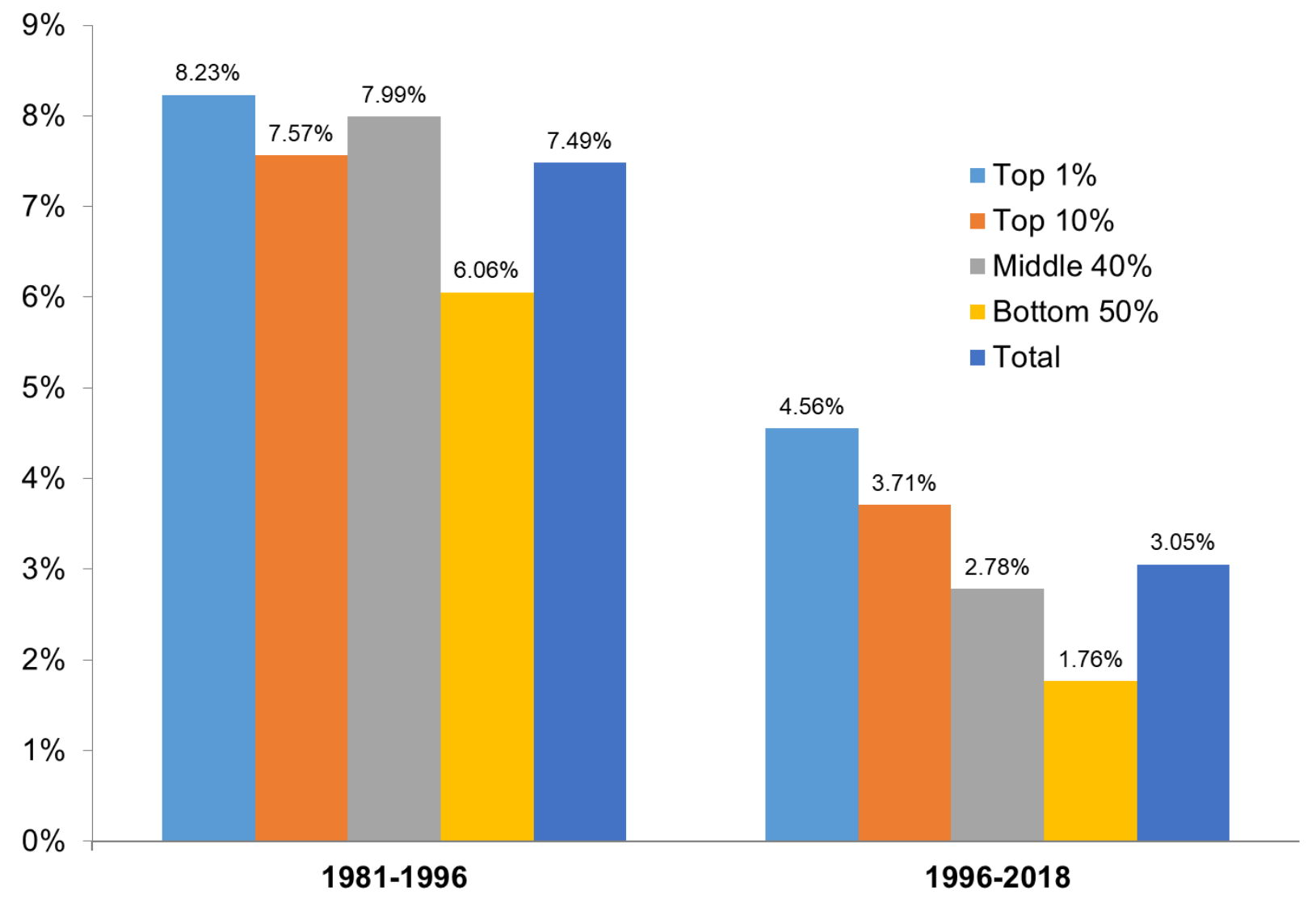


Figure 4: Overall Effects on the Change of Wage Gini by Economic Drivers

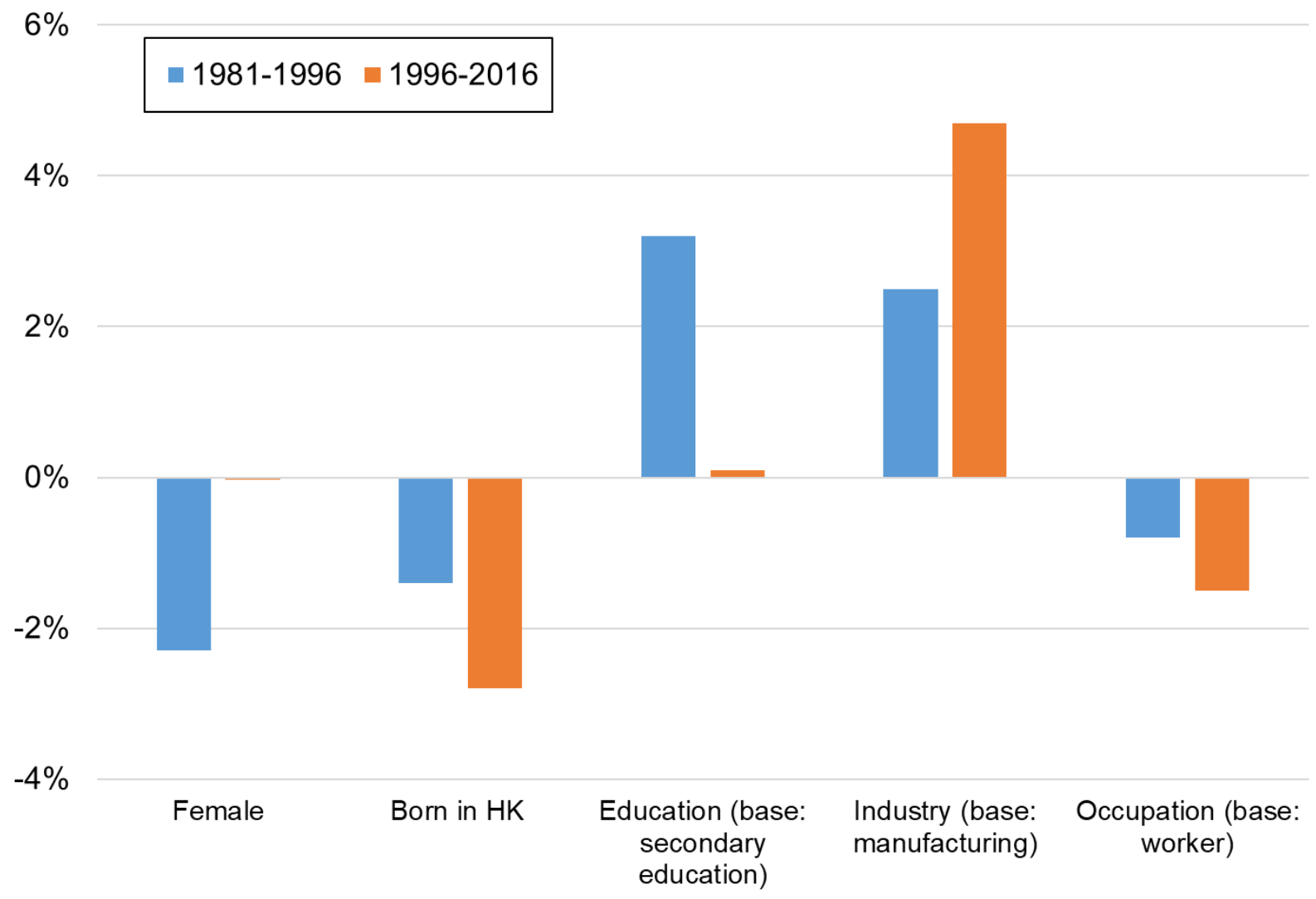


Figure 5: Capital share: Hong Kong vs. high income countries, 1991-2019

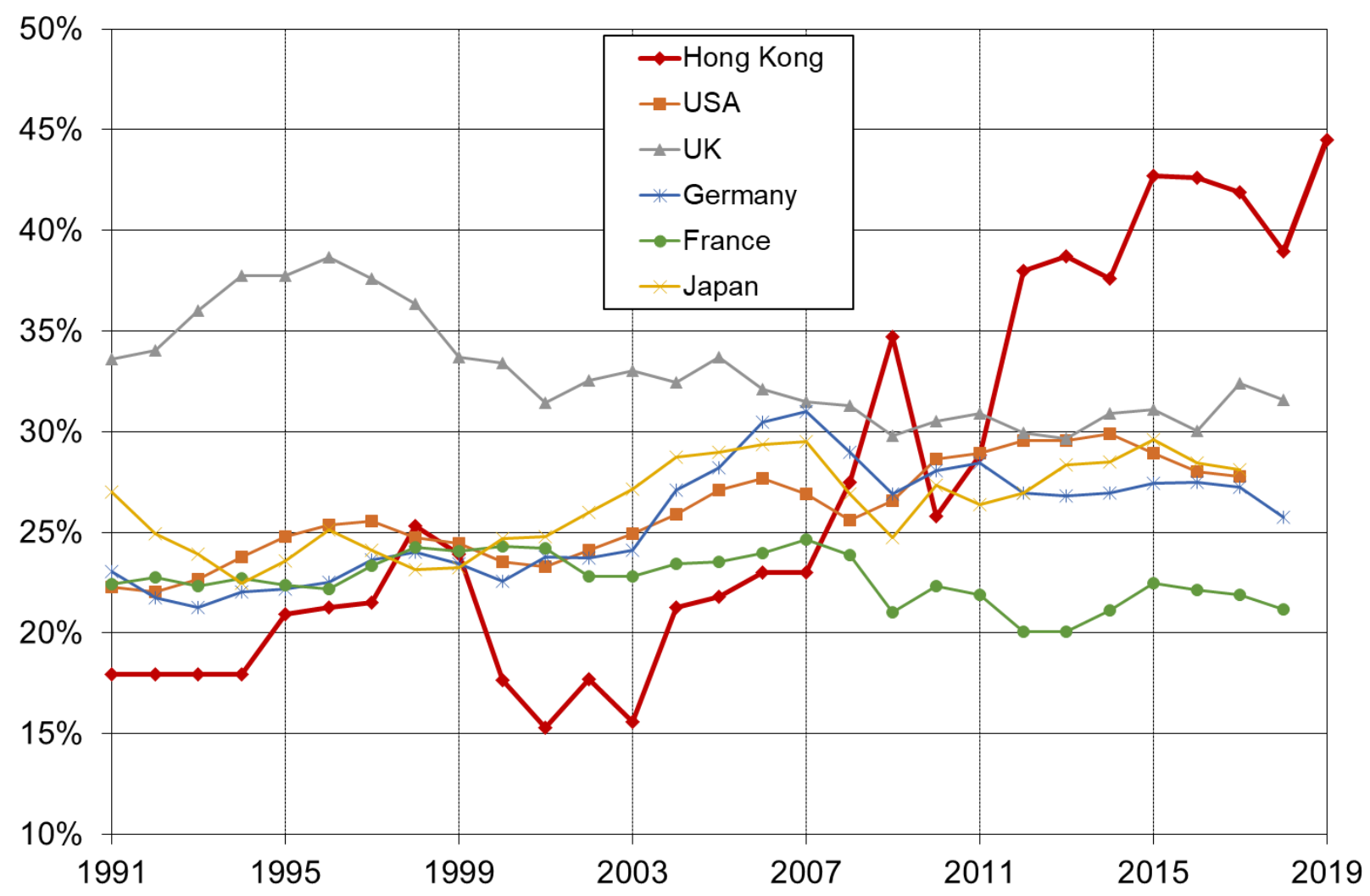


Figure 6 (Panels A and B): Density and wealth of Billionaires in 2017
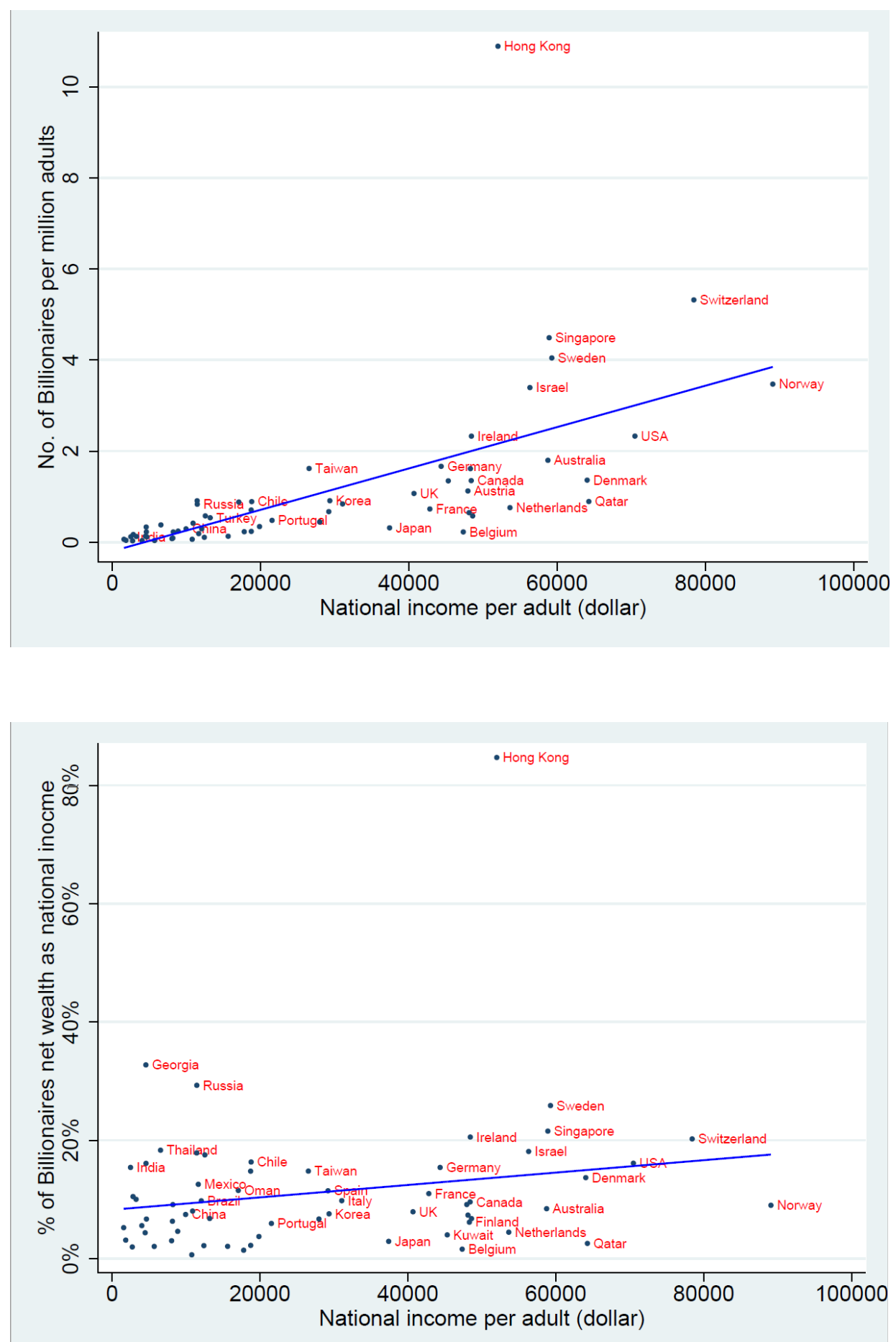
Figure 7 (Panel A and B): Top 0.001\% Wealth (as \% National Income), 1987-2020
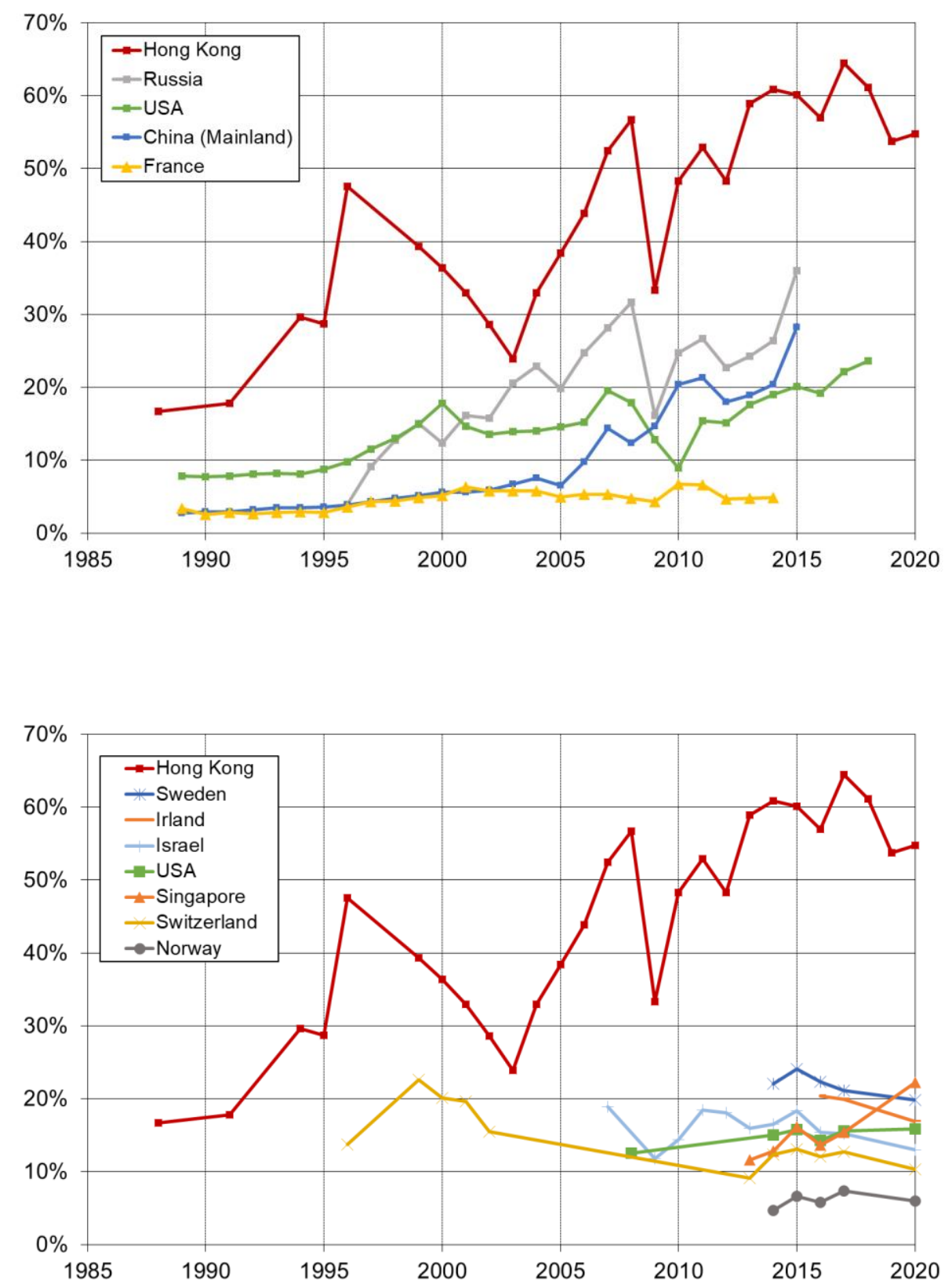
Figure 8: Evolution of Private Housing Wealth in Hong Kong and Other Major Economies (1985-2019). Housing Wealth as a Fraction of National Income (Panel A) and as a Fraction of Total Private Wealth (Panel B). Note: private housing wealth is equal to the value of domestic private housing minus housing mortgage
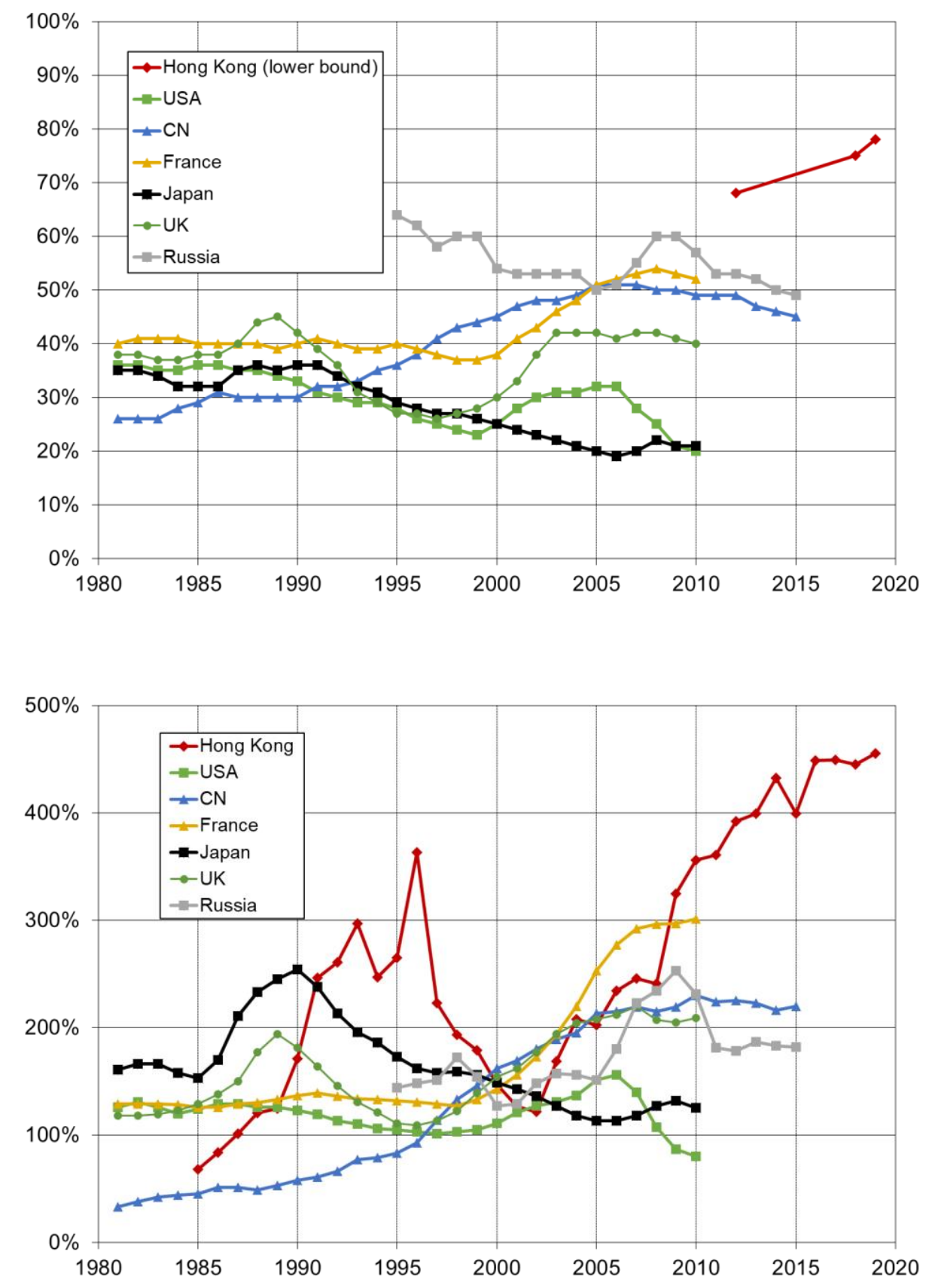
Figure 9 ( $A$ and $B$ ): Evolution of Housing and Stock Price Index and the Shang of Housing and Stock Owners in Hong Kong (1981-2016)
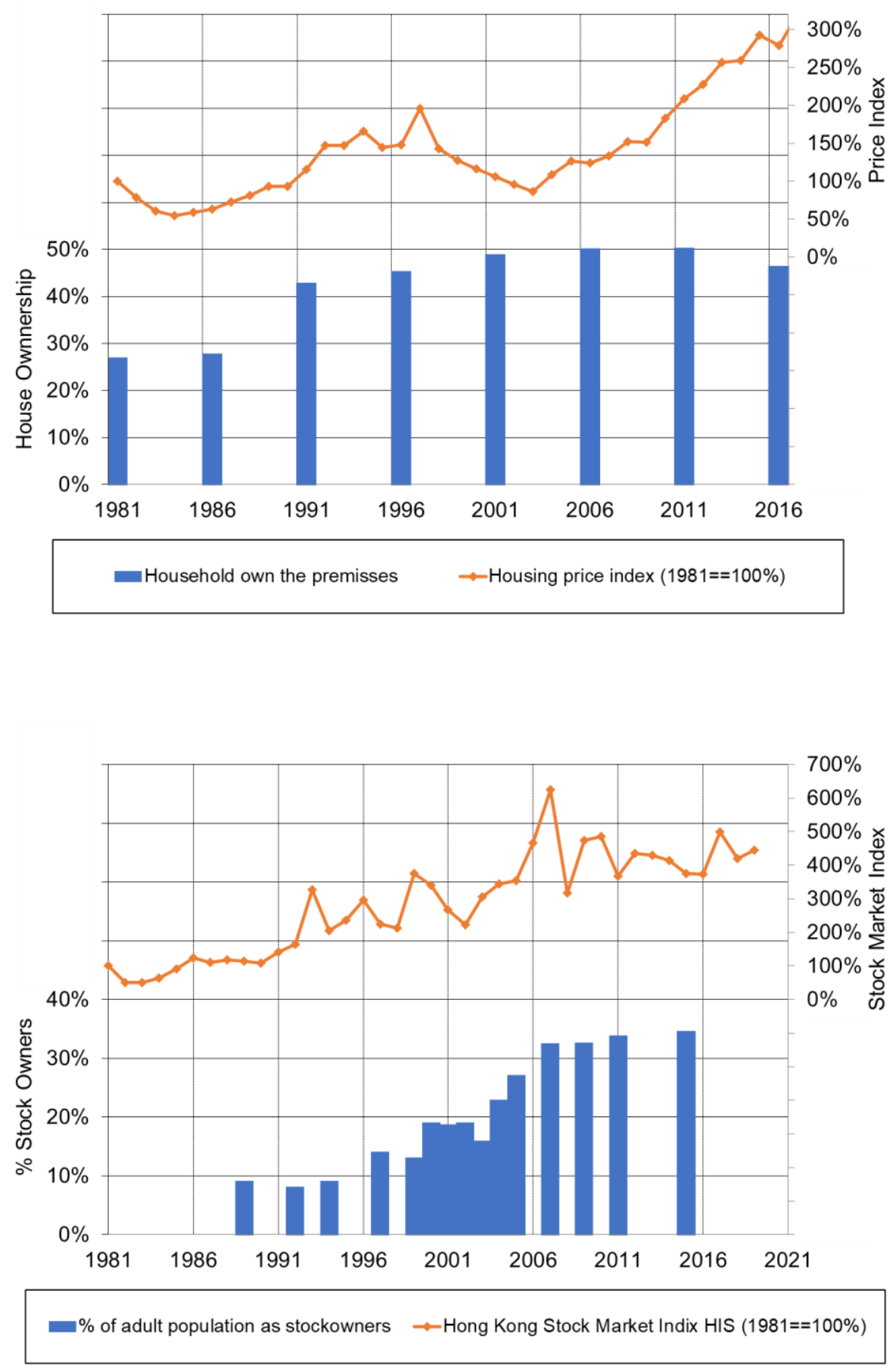
Table 1: Summary Statistics, RIF regression on Gini, and Oaxaca-Blinder decomposition for the change of Gini

\begin{tabular}{|c|c|c|c|c|c|c|c|c|c|c|}
\hline & [1] & [2] & [3] & [4] & [5] & {$[6]$} & \multicolumn{2}{|r|}{$[8]$} & \multicolumn{2}{|c|}{$[9] \quad[10]$} \\
\hline & \multicolumn{3}{|c|}{ Employee Share } & \multicolumn{3}{|c|}{ Wage Gini Coefficient } & \multicolumn{4}{|c|}{ OB decomposition of Wage Gini Coefficient } \\
\hline & & & & \multirow[t]{3}{*}{$32.7 \%$} & \multirow[t]{3}{*}{$41.3 \%$} & \multirow[t]{3}{*}{$42.8 \%$} & \multirow{2}{*}{\multicolumn{2}{|c|}{$\frac{1981 \text { vs. } 1996}{8.6 \%^{* * * *}}$}} & \multicolumn{2}{|c|}{1996 vs. 2016} \\
\hline & & & & & & & & & $1.5 \%$ & \\
\hline & 1981 & 1996 & 2016 & & & & $\begin{array}{l}\text { Composition } \\
\text { effect } \\
14.1 \% * * * \\
\end{array}$ & $\begin{array}{c}\text { Wage } \\
\text { structure } \\
-5.5 \% * * * \\
\end{array}$ & $\begin{array}{l}\text { Composition } \\
\text { effect } \\
6.9 \% * * * \\
\end{array}$ & $\begin{array}{c}\text { Wage } \\
\text { structure } \\
-5.4 \% * * *\end{array}$ \\
\hline \multicolumn{11}{|l|}{ Gender (base: Male) } \\
\hline Female & $36 \%$ & $39 \%$ & $48 \%$ & $0.072 * * *$ & 0.008 & 0.005 & $0.2 \% * * *$ & $-2.5 \% * * *$ & $0.1 \%$ & $-0.1 \%$ \\
\hline \multicolumn{11}{|c|}{ Born place (base: Not born in HK) } \\
\hline Born in Hong Kong & $48 \%$ & $68 \%$ & $72 \%$ & $0.034 * * *$ & 0.004 & $-0.035^{* * *}$ & $0.7 \% * * *$ & $-2.1 \% * *$ & $0.0 \%$ & $-\mathbf{2 . 8 \%} * * *$ \\
\hline \multicolumn{11}{|c|}{ Education (base: Secondary education) } \\
\hline Primary education & $48 \%$ & $19 \%$ & $9 \%$ & -0.009 & $0.024 * * *$ & $0.011^{* * *}$ & $0.3 \%$ & $0.6 \% * * *$ & $-0.3 \% * * *$ & $-0.1 \% * *$ \\
\hline Higher education & $7 \%$ & $22 \%$ & $44 \%$ & $0.324 * * *$ & $0.208^{* * *}$ & $0.112 * * *$ & $4.8 \% * * *$ & $-2.5 \% * * *$ & $4.7 \% * * *$ & $-4.2 \% * * *$ \\
\hline \multicolumn{11}{|l|}{ Industry (base: Manufactory) } \\
\hline Construction & $10 \%$ & $9 \%$ & $9 \%$ & $-0.031 * * *$ & -0.008 & 0.01 & $0.0 \% * *$ & $0.2 \% *$ & $0.0 \%$ & $0.2 \% *$ \\
\hline Wholesale and Retails & $9 \%$ & $15 \%$ & $19 \%$ & $-0.066^{* * * *}$ & $-0.034 * * *$ & 0.004 & $-0.4 \% * * *$ & $0.5 \% *$ & $-0.1 \% * * *$ & $0.7 \% * * *$ \\
\hline Restaurant and Hotel & $6 \%$ & $8 \%$ & $9 \%$ & $-0.090 * * *$ & 0 & $0.038 * * *$ & $-0.1 \% * * *$ & $\mathbf{0 . 7 \%} * * *$ & $0.0 \%$ & $0.3 \% * * *$ \\
\hline TSC & $8 \%$ & $11 \%$ & $13 \%$ & $-0.056 * * *$ & $-0.030 * * *$ & 0.007 & $-0.2 \% * * *$ & $0.3 \% *$ & $-0.1 \% * * *$ & $0.5 \% * * *$ \\
\hline Finance & $6 \%$ & $16 \%$ & $21 \%$ & -0.018 & $0.036^{* * * *}$ & $0.095 * * *$ & $-0.2 \%$ & $0.8 \% *$ & $0.2 \% * * *$ & $1.2 \% * * *$ \\
\hline Service & $16 \%$ & $21 \%$ & $24 \%$ & $-0.033 * *$ & $0.017^{* *}$ & $0.084 * * *$ & $-0.2 \% * *$ & $1.1 \% * * *$ & $0.1 \% * *$ & $1.6 \% * * *$ \\
\hline Others & $1 \%$ & $1 \%$ & $1 \%$ & -0.024 & -0.018 & $0.101^{* * *}$ & $0.0 \%$ & $0.0 \%$ & $0.0 \%$ & $0.1 \% * * *$ \\
\hline \multicolumn{11}{|l|}{ Occupation (base: Worker) } \\
\hline Professionals & $6 \%$ & $22 \%$ & $31 \%$ & $0.209 * * *$ & 0.003 & $-0.053 * * *$ & $3.2 \% * * *$ & $-4.5 \% * * *$ & $0.0 \%$ & $-1.7 \% * * *$ \\
\hline Administrion and Management & $3 \%$ & $9 \%$ & $10 \%$ & $0.628 * * *$ & $0.277 * * *$ & $0.312 * * *$ & $3.8 \% * * *$ & $-3.1 \% * * *$ & $0.2 \% * * *$ & $0.3 \%$ \\
\hline Clericals & $14 \%$ & $19 \%$ & $17 \%$ & $-0.053 * * *$ & $-0.046 * * *$ & $-0.072 * * *$ & $-0.3 \% * * *$ & $0.1 \%$ & $0.1 \% * * *$ & $-0.4 \% * * *$ \\
\hline Marriage (total effect) & & & & & & & $0.2 \% *$ & $1.3 \% * * *$ & $0.0 \%$ & $0.1 \%$ \\
\hline Age (total effect) & & & & & & & $1.3 \% * * *$ & $-4.9 \% * * *$ & $2.5 \% * * *$ & $-13.9 \% * * *$ \\
\hline Districts (total effect) & & & & & & & $0.9 \% *$ & $-2.9 \% * *$ & $-0.5 \% * * *$ & $-11.2 \% * * *$ \\
\hline Constants & & & & $0.364 * * *$ & $0.477 * * *$ & $0.718^{* * *}$ & & $11.3 \% * *$ & & $24.1 \% * * *$ \\
\hline R-squared & & & & 0.2018 & 0.0752 & 0.1078 & & & & \\
\hline No. of Obs & & & & 16324 & 116254 & 138772 & & & & \\
\hline
\end{tabular}


Table 2: Top Wealth Share, Wealth Income Ratio, and Normalized Top Wealth: Hong Kong vs.Other economies

\begin{tabular}{|c|c|c|c|c|c|c|}
\hline Country & Year & Share ${ }^{\text {top } 0.001 \%}$ & $\begin{array}{c}\text { Normalized Top } \\
0.001 \% \text { Wealth }\end{array}$ & $\beta_{\mathrm{t}}^{\text {private }}$ & $\beta_{\mathrm{t}}^{\text {housing }}$ & $A_{t}^{\text {housing }}$ \\
\hline South Africa & 2018 & & & $265 \%$ & & \\
\hline Norway & 2018 & & & $297 \%$ & & \\
\hline Russia & 2015 & $9.8 \%$ & $36 \%$ & $371 \%$ & & \\
\hline Germany & 2015 & & & $434 \%$ & & \\
\hline Danmark & 2018 & & & $436 \%$ & & \\
\hline China & 2015 & $5.8 \%$ & $28 \%$ & $487 \%$ & & \\
\hline Greece & 2010 & & & $518 \%$ & & \\
\hline USA & 2018 & $4.3 \%$ & $24 \%$ & $543 \%$ & & \\
\hline Canada & 2018 & & & $553 \%$ & & \\
\hline France & 2014 & $0.9 \%$ & $5 \%$ & $558 \%$ & & \\
\hline Korea & 2018 & & & $595 \%$ & & \\
\hline Japan & 2015 & & & $615 \%$ & & \\
\hline UK & 2015 & & & $617 \%$ & & \\
\hline Spain & 2017 & & & $629 \%$ & & \\
\hline Austrilia & 2018 & & & $676 \%$ & & \\
\hline Italy & 2017 & & & $701 \%$ & & \\
\hline Taiwan & 2018 & & & $837 \%$ & & \\
\hline \multirow{4}{*}{ Hong Kong } & & Lower Bound & & Upper bound & & Lower Bound \\
\hline & 2012 & $8.3 \%$ & $48 \%$ & $576 \%$ & $392 \%$ & $68 \%$ \\
\hline & 2018 & $10.3 \%$ & $61 \%$ & $593 \%$ & $445 \%$ & $75 \%$ \\
\hline & 2019 & $9.3 \%$ & $54 \%$ & $583 \%$ & $455 \%$ & $78 \%$ \\
\hline
\end{tabular}


Table 3: Simulation for evolution of wealth inequality in Hong Kong (1996-2016)

\begin{tabular}{|c|c|c|c|c|c|c|c|c|c|c|c|c|c|c|c|}
\hline & \multicolumn{12}{|c|}{ Simulation Parameters } & \multicolumn{3}{|c|}{ Simulation Results } \\
\hline & \multirow[b]{2}{*}{$\begin{array}{c}\text { Rate of } \\
\text { return }\end{array}$} & \multirow[b]{2}{*}{$\begin{array}{c}\text { Capital } \\
\text { share }\end{array}$} & \multirow[b]{2}{*}{$\begin{array}{c}\text { Private } \\
\text { saving } \\
\text { rate }\end{array}$} & \multicolumn{3}{|c|}{ Capital gain on different assets } & \multicolumn{3}{|c|}{ Asset portfolio } & \multirow[b]{2}{*}{$\begin{array}{l}\text { Capital } \\
\text { gain on } \\
\text { all assets }\end{array}$} & \multirow{2}{*}{$\begin{array}{c}\text { Relative } \\
\text { capital } \\
\text { gain } \\
\text { premium }\end{array}$} & \multirow{2}{*}{$\begin{array}{c}\text { Relative } \\
\text { rate of } \\
\text { return } \\
\text { premium }\end{array}$} & \multirow[b]{2}{*}{$\begin{array}{l}\text { Price } \\
\text { effect }\end{array}$} & \multirow[b]{2}{*}{$\begin{array}{l}\text { Saving } \\
\text { effect }\end{array}$} & \multirow[b]{2}{*}{$\begin{array}{l}\text { Total } \\
\text { effect }\end{array}$} \\
\hline & & & & $\begin{array}{l}\text { Capital } \\
\text { gain on } \\
\text { housing } \\
\end{array}$ & $\begin{array}{l}\text { Capital } \\
\text { gain on } \\
\text { equities }\end{array}$ & $\begin{array}{l}\text { Capital } \\
\text { gain on } \\
\text { savings } \\
\end{array}$ & $\begin{array}{l}\text { Share of } \\
\text { housing }\end{array}$ & $\begin{array}{c}\text { Share of } \\
\text { equities }\end{array}$ & $\begin{array}{c}\text { Share of } \\
\text { savings }\end{array}$ & & & & & & \\
\hline & $r_{t}$ & $\alpha_{\mathrm{t}}$ & $\mathrm{s}_{\mathrm{t}}$ & $q_{t}^{\text {housing }}$ & $q_{t}{ }^{\text {equity }}$ & $q_{t}^{\text {savings }}$ & $A_{t}^{\text {housing }}$ & $A_{t}{ }^{\text {equity }}$ & $A_{t}^{\text {savings }}$ & $\mathrm{q}_{\mathrm{t}}$ & $\phi_{t}^{\mathrm{q}, \mathrm{i}}$ & $\phi_{\mathrm{t}}^{\mathrm{r}, \mathrm{i}}$ & & & \\
\hline National & $164 \%$ & $29 \%$ & $12 \%$ & $89 \%$ & $26 \%$ & $0 \%$ & $60 \%$ & $20 \%$ & $20 \%$ & $59 \%$ & & & & & \\
\hline Top & & $80 \%$ & $40 \%$ & & $26 \%$ & & $0 \%$ & $100 \%$ & $0 \%$ & $26 \%$ & $45 \%$ & $150 \%$ & $-14 \%$ & $23 \%$ & $9 \%$ \\
\hline Bottom & & $0 \%$ & $0 \%$ & & & & $0 \%$ & $0 \%$ & $100 \%$ & $0 \%$ & $0 \%$ & $100 \%$ & $-26 \%$ & $-31 \%$ & $-56 \%$ \\
\hline
\end{tabular}


Table 4: Summary Statistics and Logit Regression on Political Inclination

\begin{tabular}{|c|c|c|c|c|c|c|c|}
\hline \multirow[b]{2}{*}{ Political inclination } & \multicolumn{4}{|c|}{ Summary Statistics } & \multicolumn{3}{|c|}{ Logit Regression on Political inclination } \\
\hline & $\begin{array}{c}\text { Full Sample } \\
{[1]} \\
\end{array}$ & $\begin{array}{c}\text { pro- } \\
\text { establishme } \\
{[2]} \\
\end{array}$ & $\begin{array}{c}\text { Centrist } \\
{[3]}\end{array}$ & $\begin{array}{c}\text { Pro- } \\
\text { democracy } \\
{[4]} \\
\end{array}$ & $\begin{array}{c}\text { Pro-establishment } \\
\text { Camp } \\
{[5]} \\
\end{array}$ & $\begin{array}{c}\text { Centrist } \\
{[6]}\end{array}$ & $\begin{array}{c}\text { Pro-democracy } \\
\text { Camp } \\
{[7]} \\
\end{array}$ \\
\hline Political inclination & $100 \%$ & & & & & & \\
\hline Pro-Beijing & $14.0 \%$ & & & & & & \\
\hline Centrist & $32.4 \%$ & & & & & & \\
\hline Pro-democracy & $36.9 \%$ & & & & & & \\
\hline Others & $16.7 \%$ & & & & & & \\
\hline $\begin{array}{l}\text { Top income dummy } \\
\text { (monthly income higher than } 5160 \text { US\$) }\end{array}$ & $14.5 \%$ & $14.3 \%$ & $15.0 \%$ & $14.5 \%$ & $\begin{array}{c}0.179 \\
(0.179)\end{array}$ & $\begin{array}{r}0.230 * * \\
(0.115)\end{array}$ & $\begin{array}{c}-0.130 * * * \\
(0.029)\end{array}$ \\
\hline Occupation 1 (base line: Executives and Manageı & $100 \%$ & $100 \%$ & $100 \%$ & $100 \%$ & & & \\
\hline Excutives and Managers & $12.4 \%$ & $14.6 \%$ & $13.7 \%$ & $12.4 \%$ & & & \\
\hline Professionals & $15.7 \%$ & $10.6 \%$ & $16.5 \%$ & $20.0 \%$ & $\begin{array}{c}-0.502 * * * \\
(0.079)\end{array}$ & $\begin{array}{l}-0.068 \\
(0.101)\end{array}$ & $\begin{array}{c}0.351 * * * \\
(0.111)\end{array}$ \\
\hline Clerical and service workers & $16.8 \%$ & $13.3 \%$ & $18.2 \%$ & $17.0 \%$ & $\begin{array}{c}-0.408^{* *} \\
(0.204)\end{array}$ & $\begin{array}{l}-0.007 \\
(0.079)\end{array}$ & $\begin{array}{c}0.194 \\
(0.151)\end{array}$ \\
\hline Production workers & $7.1 \%$ & $9.3 \%$ & $8.1 \%$ & $5.3 \%$ & $\begin{array}{l}-0.060 \\
(0.369)\end{array}$ & $\begin{array}{c}0.136 \\
(0.164)\end{array}$ & $\begin{array}{l}-0.121 \\
(0.076)\end{array}$ \\
\hline Students & $7.2 \%$ & $1.8 \%$ & $5.2 \%$ & $12.9 \%$ & $\begin{array}{c}-1.111 * * * \\
(0.344)\end{array}$ & $\begin{array}{c}-0.692 * * * \\
(0.104)\end{array}$ & $\begin{array}{c}0.961 * * * \\
(0.133)\end{array}$ \\
\hline Housewives & $12.4 \%$ & $11.6 \%$ & $14.0 \%$ & $9.7 \%$ & $\begin{array}{l}-0.282 \\
(0.285)\end{array}$ & $\begin{array}{c}0.151 * * * \\
(0.056)\end{array}$ & $\begin{array}{c}0.041 \\
(0.165)\end{array}$ \\
\hline Others (retirees ect.) & $28.5 \%$ & $38.9 \%$ & $24.5 \%$ & $22.7 \%$ & $\begin{array}{l}-0.105 \\
(0.210)\end{array}$ & $\begin{array}{c}-0.157^{*} \\
(0.094)\end{array}$ & $\begin{array}{c}0.114 \\
(0.085)\end{array}$ \\
\hline Age & 50 & 57 & 49 & 47 & $\begin{array}{c}0.019^{* * * *} \\
(0.005)\end{array}$ & $\begin{array}{c}-0.007 * * * \\
(0.002)\end{array}$ & $\begin{array}{c}-0.011^{* * * *} \\
(0.001)\end{array}$ \\
\hline Female & $50.8 \%$ & $44.2 \%$ & $50.8 \%$ & $48.5 \%$ & $\begin{array}{l}-0.240^{*} \\
(0.125)\end{array}$ & $\begin{array}{c}0.026 \\
(0.174)\end{array}$ & $\begin{array}{l}-0.133 \\
(0.116)\end{array}$ \\
\hline Education (base dline: Secondary educaiton) & $100.0 \%$ & $100.0 \%$ & $100.0 \%$ & $100.0 \%$ & & & \\
\hline Secondary education & $44.9 \%$ & $55.8 \%$ & $46.1 \%$ & $38.2 \%$ & & & \\
\hline Primary education & $12.5 \%$ & $12.4 \%$ & $10.9 \%$ & $8.2 \%$ & $\begin{array}{c}-0.568 * * * \\
(0.188)\end{array}$ & $\begin{array}{l}-0.098 \\
(0.150)\end{array}$ & $\begin{array}{c}-0.149 * * \\
(0.071)\end{array}$ \\
\hline Junior Colloge & $8.7 \%$ & $6.3 \%$ & $9.2 \%$ & $9.6 \%$ & $\begin{array}{c}-0.350 * * * \\
(0.086)\end{array}$ & $\begin{array}{c}0.052 \\
(0.071)\end{array}$ & $\begin{array}{c}0.139 * * * \\
(0.034)\end{array}$ \\
\hline Bachelor & $26.3 \%$ & $19.9 \%$ & $26.0 \%$ & $33.7 \%$ & $\begin{array}{c}-0.254 * * \\
(0.125)\end{array}$ & $\begin{array}{l}-0.098 \\
(0.116)\end{array}$ & $\begin{array}{c}0.377^{* * * *} \\
(0.051)\end{array}$ \\
\hline Above Bachalor & $7.7 \%$ & $5.6 \%$ & $7.7 \%$ & $10.3 \%$ & $\begin{array}{c}-0.519^{* * * *} \\
(0.159)\end{array}$ & $\begin{array}{l}-0.188 \\
(0.133)\end{array}$ & $\begin{array}{c}0.650 * * * \\
(0.121)\end{array}$ \\
\hline Constants & & & & & $\begin{array}{c}-2.457 * * * * \\
(0.306) \\
\end{array}$ & $\begin{array}{l}-0.275 \\
(0.217) \\
\end{array}$ & $\begin{array}{c}-0.264^{*} \\
(0.146) \\
\end{array}$ \\
\hline Observations & & & & & 4,310 & 4,310 & 4,310 \\
\hline Log pseudolikelihood & & & & & -1673 & -2686 & -2704 \\
\hline District Fixed Effect & & & & & $\mathrm{Y}$ & $\mathrm{Y}$ & $\mathrm{Y}$ \\
\hline Cluster at District Level & & & & & $\mathrm{Y}$ & $\mathrm{Y}$ & $\mathrm{Y}$ \\
\hline
\end{tabular}




\title{
Income and Wealth Inequality in Hong Kong, 1981-2020: The Rise of Pluto-Communism?
}

\author{
Appendix \\ Thomas Piketty \\ Li Yang
}

June 2021

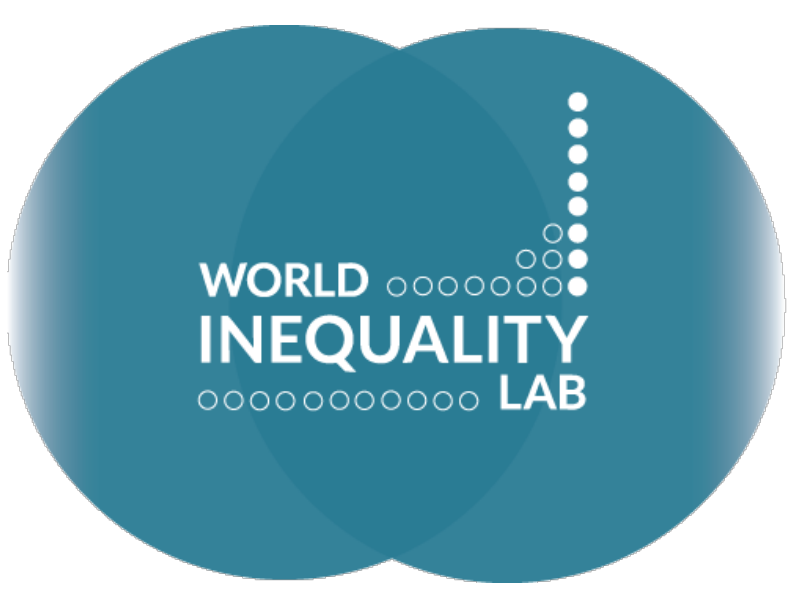

WID.WORLD

THE SOURCE FOR

GLOBAL INEQUALITY DATA 


\section{Appendix A-E}

\section{Appendix A: Data Description}

Our study relies on below five main data sources.

1. HK Salaries Tax Assessment (1973 - 2018) and HK Corporate Profit Tax (1989-2018)

2. HK Census Micro data for 1981, 1986, 1991, 1996, 2001, 2006, 2011, 2016.

3. HK Rich List (1996 - 2020)

4. HK National Account (1980-2020)

5. HK pre-nomination Survey for 2016 Legislative Council Election

Below we will explain each data source in details.

\section{HK Salaries Tax Assessment (1973-2017) and HK Corporate Profit Tax (1989-2018)}

Both data sets are provided by the HK Inland Revenue Department Annual Report. HK Salaries Tax Assessment covers only the salaries income (including employer's contribution for retirement schemes). Both total income and chargeable income are reported. Hong Kong corporate profits tax covers profits from both domestic and foreign corporations as well as domestic and foreign unincorporated businesses in Hong Kong. Unincorporated business does not possess a separate legal identity from its owner(s). The owner(s) bear full liability for any action or inaction of the business: they may sue and be sued for business activity or inactivity. Unincorporated enterprises include sole proprietor-ships, partnerships and family trusts. For details, please see https://www.ird.gov.hk/eng/paf/pam.htm\#stpa.

\section{HK Census}

Micro sample data set is purchased from Census and Statistic Department. For wave 1981 and 1986, the sample data set covers $1 \%$ of the Census. For the rest of the waves, the sample data set covers $5 \%$ of the Census.

\section{a. Sampling approach}

The sampling approach has been changed periodically. Caution is required when comparing statistic results across different waves.

1981, 1986, 1991: de facto enumeration approach.

1996: de jure enumeration approach.

2001, 2006, 2011, 2016: Resident population approach.

\section{b. Income Variables}

The census income variables have two constraints:

First, both household income and individual income are top-coded. Taking individual income from employment as an example, monthly income above $99,998 \mathrm{HKD}$ is top-coded in wave 1981 to 1991; monthly income above 
150,000 is top-coded in wave 1996-2016. The share of population with top-coded income varies from $1 \%$ to $2.5 \%$. Nationally, on option to correct such census data is to apply the top correction using salary tax data.

Second, there are only two income sources for individual income:

Income from employment: for employers or self-employed persons, this is the amount earned excluding expenses incurred in running their main business; for employees, this is the total amount earned from their main employment including salary or wage, bonus, commission, overtime, housing allowance, tips and other cash allowances.

Income from other sources: rent income, interest, dividend, education grants (excluding loan), regular/monthly pensions, social security payment, old age allowance, disability allowance, comprehensive social security assistance, scholarships, regular, contribution from persons outside the household, contribution from charities.

Potentially, one could use the information contained in Employment Status to split income from employment into wage income and business income.

\section{HK Rich List (1988 - 2019)}

Wealth data in HK is very limited. Our rich list is retrieved from Forbes magazine. Before 2007 HK data is from the world billionaires list. From 2008 to 2012, the data is from the Hong Kong's 40 Richest. Since 2013 data is from the Hong Kong's 50 Richest.

\section{HK National Account (1980-2016)}

Our data is from UN and Census and Statistic Department. The National Accounts of Hong Kong are highly aggregated. Only decomposition of primary income account and external account for total economy are available. For details, please Appendix D: HKG_NA.xlsx

\section{HK Survey for 2016 Legislative Council Election}

HK election survey data is from the Public Opinion Program (POP) of The University of Hong Kong (HKU).

The Pre-nomination Survey for 2016 Legislative Council Election was conducted between June 20 and July 8, 2016 over 5,084 adult registered voters in Hong Kong who speak Cantonese. The pre-nomination survey contains information of interviewee of gender, age, education level, occupation, income level, and residential district, and political inclination.

The 2016 Election Rolling Survey is a daily rolling survey, conducted from July 30 to September 2 2016. For each day it interviews daily interviewing at least 200 adult registered voters in Hong Kong who speak Cantonese. it provides less detailed information on education levels and occupation than the pre-nomination survey.

For more details of both surveys, pleases see https://develo.pori.hk 


\section{Appendix B: Codebook of harmonized dataset of Hong Kong Census}

1. year: census year

2. DIST1: residential area, 1981, 1986, 1996, 2001, 2006, 2011, 2016

Hong Kong Island

Kowlong

New Territories

3. DIST2: residential area, sub-district level, 1981, 1986, 1996, 2001, 2006, 2011, 2016

\begin{tabular}{|c|c|c|}
\hline 2 & Central and Western & 中西区 \\
\hline 3 & Wan Chai & 湾仔区 \\
\hline 4 & Eastern & 东区 \\
\hline 5 & Southern & 南区 \\
\hline 6 & Yau Tsim Mong & 油尖旺区 \\
\hline 7 & Sham Shui Po & 深水涉区 \\
\hline 8 & Kowloon City & 九龙城区 \\
\hline 9 & Wong Tai Sin & 黄大仙区 \\
\hline 10 & Kwun Tong & 观塘区 \\
\hline 11 & Sai Kung (Tseung Kwan O) & 西贡区 1 \\
\hline 12 & Sai Kung (Other Areas) & 西贡区 2 \\
\hline 13 & Tsuen Wan (New Town) & 荃湾区 1 \\
\hline 14 & Tsuen Wan (Other Areas) & 荃湾区 2 \\
\hline 15 & Tuen Mun (New Town) & 屯门区 1 \\
\hline 16 & Tuen Mun (Other Areas) & 屯门区 2 \\
\hline 17 & Yuen Long (New Town) & 元朗区 1 \\
\hline 18 & Yuen Long (Tin Shui Wai) & 元朗区 2 \\
\hline 19 & Yuen Long (Other Areas) & 元朗区 3 \\
\hline 20 & North (New Town) & 北区 1 \\
\hline 21 & North (Other Areas) & 北区 2 \\
\hline 22 & Tai Po (New Town) & 大埔区 1 \\
\hline 23 & Tai Po (Other Areas) & 大埔区 2 \\
\hline 24 & Sha Tin (New Town) & 沙田区 1 \\
\hline 25 & Sha Tin (Ma On Shan) & 沙田区 2 \\
\hline 26 & Sha Tin (Other Areas) & 沙田区 3 \\
\hline 27 & Kwai Tsing (Kwai Chung) & 葵青区 1 \\
\hline 28 & Kwai Tsing (Tsing Yi) & 葵青区 2 \\
\hline 29 & Kwai Tsing (Other Areas) & 葵青区 3 \\
\hline 30 & Islands & 离岛区 \\
\hline 91 & Marine & \\
\hline
\end{tabular}


4. lq: living quarter ID

5. hh: household ID

6. ind: individual ID. In 1986, 3345 missing value.

7. wt_lq: living quarter weight. It is equal to 1 for all years.

8. wt_hh: household weight. It is equal to 1 for year 1981, 1986

9. wt ind: individual weight. It is equal to 1 for year 1981, 1986

10. tnr: tenure type (household level)

1. Own the premises

2. Sole tenant

3. Co-tenant

4. Main-tenant

5. Sub-tenant

6. Rent free

7. Provided or subsidized by employer

8. N.A.

11. rent: monthly Household Rent paid. It includes rates for that month but excludes payments for water, electricity and management fee.

12. mrtg: monthly mortgage paid, 2001, 2006, 2011, 2016.

13. mrtgyr: mortgage year left, 2001, 2006, 2011, 2016.

14. hhinc: monthly household income. There are missing values

15. hhsize: household size

16. hhadt: number of adult in household

17. age: age, when age $=75$, it includes $75+$.

18. pob: place of birth. In 1986, only including 3 categories HK, China (main), Other. In 1981 China (main) including China mainland and Macro; in the rest of the years China (main) including China mainland and Macro and Taiwan.

1. HK

2. China(main)

3. Japan

4. South Asia

5. UK

6. North America

7. Australia

8. Others

19. nat: nationality, 1991, 1996, 2001, 2006, 2011, 2016.
a. British
b. HK Chinese
c. Other Chinese
d. Filipino
e. N. American

f. S. Asian 

g. Thai
h. Japanese
i. Austria
j. Other

20. lan: language spoken at home, 1991, 1996, 2001, 2006, 2011, 2016.
a. Cantonese
b. English
c. Putonghua
d. ChiuChau
e. Hakka
f. Fukien
g. SzeYap
h. Shanghainess
i. OtherChineseDialects
j. Filipino
k. Japanese
1. Others

21. mar: marital status

1. Single

2. Married

3. Widowed

4. Divorced/Separated

22. edu: educational attainment (highest level attended)

1. No Schooling

2. Primary

3. Secondary

4. Craft

5. Colleges and Polytechnic

6. University

7. Post-graduate

23. emp: employment status. In 1991, selfemployed (Hawking) and selfemployed (others) are combined in one category, selfemployed.

1.1 Employees

1.2 Employer

1.3 Selfemployed (Hawking)

1.4 Selfemployed (Others)

1.5 Unpaid worker

2. Unemployed

3.1 Home-maker

3.2 Student

3.3 Of Independent means 
3.4 Retired

3.5 Others

24. occ: occupation. For all years, "Worker" includes sales worker, services worker, skilled worker and elementary worker

1. Professions

2. Adm \& Managerial

3. Clericals

4. Worker

4.1 Sales Worker

4.2 Services Worker

4.3 Skilled Worker

4.4 Elementary Worker

25. inds: Industry.

a. Agriculture ${ }^{1}$

b. Minging

c. Manufacturing

d. Electricity, Gas and Water

e. Construction

f. Wholesale and Retail

g. Restaurant and Hotel

h. TSC

i. Financial

j Servince

26. inc_wage: monthly income of employees

27. inc_busi: monthly income of employer and self-employed person

28. inc_oth ${ }^{2}$ : monthly income from other sources. See definition for various years below

1981: rent, dividend, interest, pension, remittance, social welfare payment, ect.

1986: secondary employment earnings, interest, rent, social welfare payment, old age allowance ect.

1991-1996: interest, dividend, rental, welfare payment, old allowane etc.

2001-2016: rent income, interest, dividend, education grants (excluding loan), regular/monthly pensions, social security payment, old age allowance, disablity allowance, comprehensive social security assistance, scholarships, regular, contribution from persons outside the household, contribution from charities.

1 Industrial code, 2016:HSIC v2.0 (adjusted using HISC v1.1); 2011: HSIC v1.1; 1991, 1996: SIC1991

2 Note that inc_wage and inc_oth includes income for retired person. 


\section{Appendix C: Methodology for constructing wage and total income series}

In this section, we describe step-by-step how we construct the inequality series of wage and total income in Hong Kong.

\section{Wage Distribution}

Step 1. We start by estimating the wage distributional series (svy_wage $\mathbf{e}^{\mathbf{3}}$ ) using Hong Kong income survey data (sample datasets from Hong Kong population census). However, there are two concerns:

i) the wage income (as well as other income variables) in the survey are top-coded and the share of topcoded observations of the sample increases along the time, i.e. in $19910.07 \%$ of the sample are topcoded with wage income, in 2016 the share increased 5 times to $0.35 \%$. (For more details on top-coding, please see Appendix D, Sheet AX5.) Naturally top-coded sample will generate a downwards bias to the top of the distribution.

ii) Surveys often fails at capturing the top income because individuals from high-income strata typically have very low response rates in surveys.

Step 2. We first correct the top coding issue. We assume that the top of the wage distribution of Hong Kong follows a Pareto distribution. This allows us to estimate the Pareto coefficient $\alpha$ using the data (shortly) before the cut off $C$. Then using estimated $\hat{\alpha}$ and $C$, we could estimate the wage mean of the top-coded observations, which is subsequently assigned to all observations in the top-coded group. We then estimate the wage distributional series based on the uncoded survey (uncoded_svy_wage). See example below.

As an example, the graph below shows the how we estimate the Pareto coefficient a for wage distribution in 2016.

i) Using the observations from p99-p99.6, we estimate the Pareto coefficient $\alpha=0.498$.

ii) We calculate $b$ coefficient using $\alpha, b=1 /(1-\alpha)=1.99$.

iii) We estimate the mean for the top-coded group with $b$ and the threshold of cutoff (1.8 million HKD), Mean_top $=1.8 * b=3.587$ million HKD

iv) Replace wage to 3.587 million HKD if they were equal to 1.8 million HKD.

\footnotetext{
3 Including wage and pension income
} 


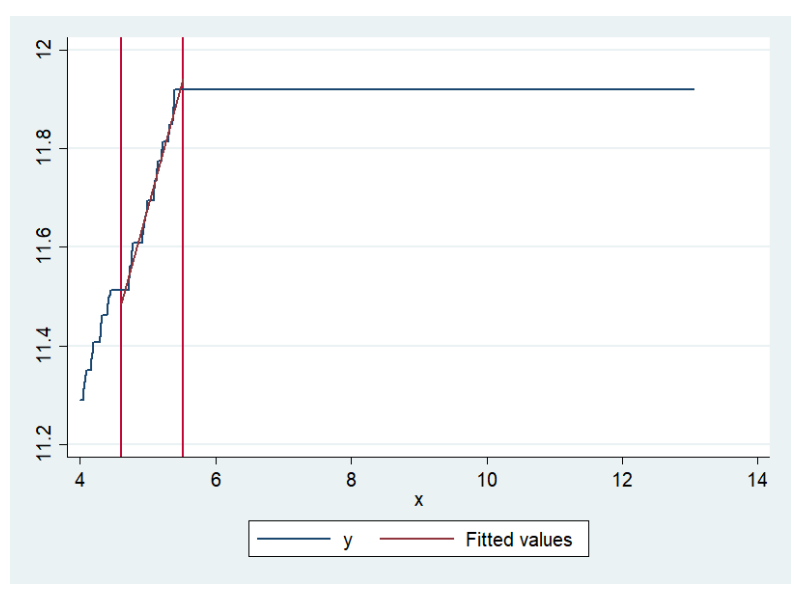

Step 3. To overcome the problem regarding missing survey data for the top incomes, we correct the uncoded survey using fiscal data. To do so, we adopt the novel reweighting method proposed in Blanchet, Flores, Morgan (2018). The basic idea is to adjust the weight of the survey ${ }^{4}$ using fiscal data in a nonparametric manner ${ }^{5}$ under the assumption that tax data sets a credible lower bound on the number of people with given levels of income. Rather than directly making assumptions regarding the behavior of complex statistics such as quantiles or bracket averages (i.e., Piketty, Yang, and Zucman, 2019; Chancel and Piketty, 2017; Czajka, 2017; Morgan, 2017), their method makes easily interpretable assumptions at the observation level. Most importantly, this method allows us to correct the income distribution without losing the richness of the information in surveys. Therefore, in the adjusted survey data, the representativeness in terms of age, gender, or ethnicity, in the case of this research, will be maintained. We then estimate the wage distributional series based on the adjusted survey (adjusted_svy_wage).

Step 4. Until now we use individual adult as the unit of observation. In this step, we convert the individual adult wage into the wage equal-split among the adults in the household, and estimate the wage distributional series for survey (svy_wage_eq), uncoded survey (uncoded_svy_wage_eq), and adjusted survey (adjusted_svy_wage_eq), which we will use as our bench mark series.

We provide the full results of the correction and the corresponding computer code used for applying the method in DataAppenidx.

\footnotetext{
4 In addition to adjusting the weight of the survey, the reweighting method also adjust the very top incomes by adding observations.

5 in contrast to previous reweight methods used in the literature, Blanchet, Flores, Morgan (2018) use a data-driven method, instead of relying on ad hoc assumptions and parameters, to determine where the bias starts in the survey data and beyond which point incomes are merged from tax data into the survey data.
} 


\section{Total Income Distribution}

In our sample we define total income equal to sum of wage income, business income, other income. Other income includes transfer income, rent and capital income (excl. pension).

Step 1. We start with raw survey data (svy_inc). Following the similar approach above we correct the top-coded observations on wage, business and other income (uncoded_svy_inc).

Step 2. Using uncoded survey, we then convert the individual adult total income into the total income equal-split among the adults in the household (uncoded_svy_inc_eq).

Step 3. We generate upgrade factor for each g-percentile using equal split wage distribution from uncoded survey (uncoded_svy_wage_eq) and adjusted survey (adjusted_svy_wage_eq).

Upgrade factor (by g-percentile) $=$ (mean_wage in adjusted survey $) /($ mean_wage in uncoded survey $)$

Step 4. Then we apply the upgrade factor to each g-percentile of total income in uncoded survey and estimate the corrected total income distribution series (adjusted_svy_inc_eq). 


\section{Appendix D: Income and Wealth Data Set}

See file HKG_NA.xlsx

\section{Appendix E: Main Figures and Tables}

See file MainFiguresTables.xlsx 